National Wildlife Health Center

\title{
Anisakiosis and Pseudoterranovosis
}

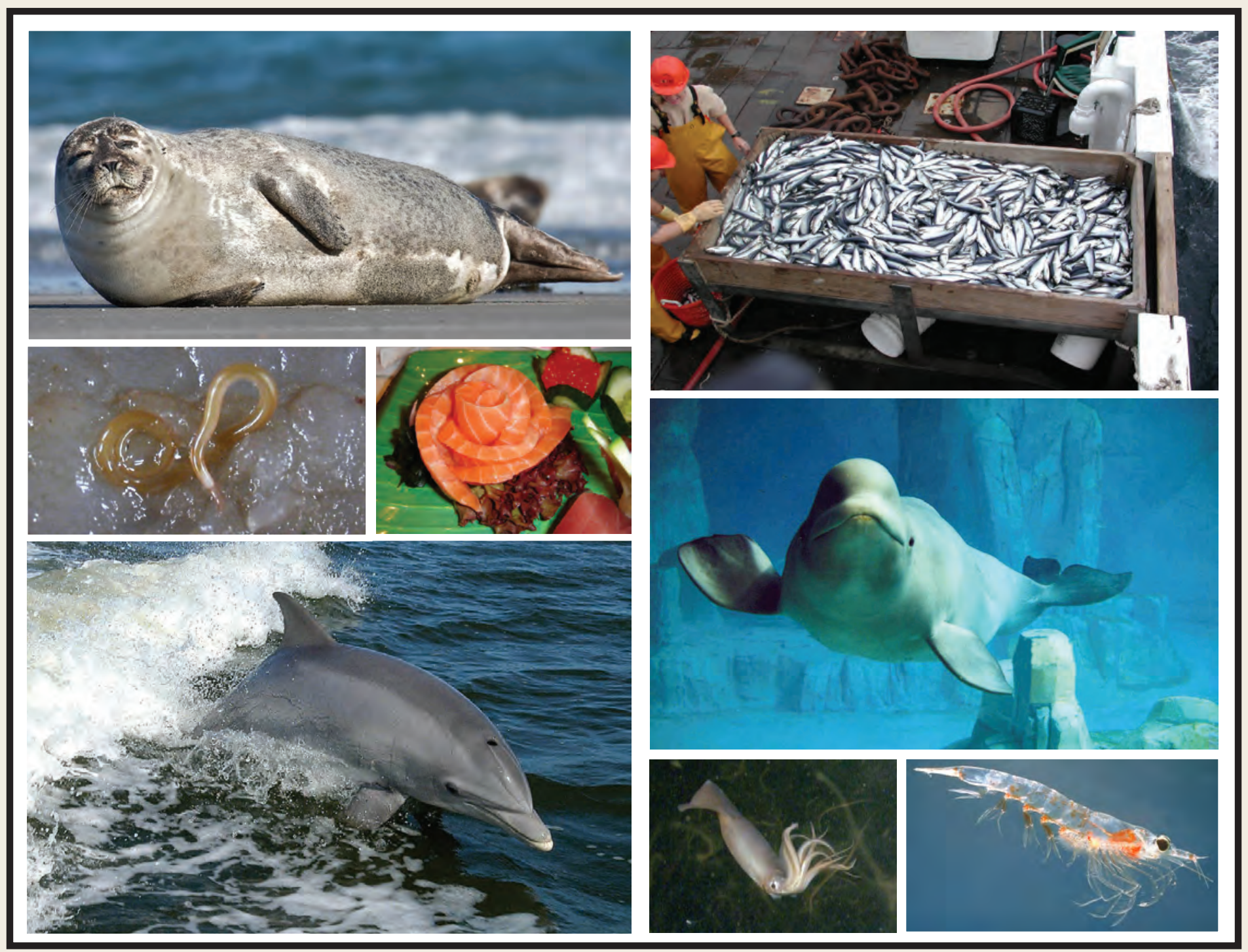

Circular 1393 


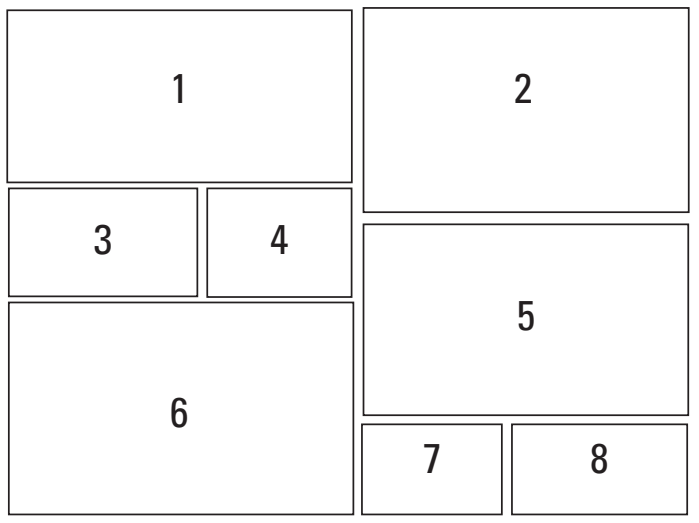

Cover: 1. Common seal, by Andreas Trepte, CC BY-SA 2.5; 2. Herring catch, National Oceanic and Atmospheric Administration; 3. Larval Pseudoterranova sp. in muscle of an American plaice, by Dr. Lena Measures;

4. Salmon sashimi, by Blu3d, Lilyu, GFDL CC BY-SA3.0; 5. Beluga whale, by Jofre Ferrer, CC BY-NC-ND 2.0;

6. Dolphin, National Aeronautics and Space Administration;

7. Squid, National Oceanic and Atmospheric Administration; 8. Krill, by Oystein Paulsen, CC BY-SA 3.0. 


\section{Anisakiosis and Pseudoterranovosis}

By Lena N. Measures

Edited by Rachel C. Abbott and Charles van Riper, III

USGS National Wildlife Health Center

Circular 1393

U.S. Department of the Interior

U.S. Geological Survey 


\title{
U.S. Department of the Interior SALLY JEWELL, Secretary
}

\section{U.S. Geological Survey \\ Suzette M. Kimball, Acting Director}

\author{
U.S. Geological Survey, Reston, Virginia: 2014
}

For more information on the USGS - the Federal source for science about the Earth, its natural and living resources, natural hazards, and the environment-visit http://www.usgs.gov or call 1-888-ASK-USGS

For an overview of USGS information products, including maps, imagery, and publications, visit http://www.usgs.gov/pubprod

To order this and other USGS information products, visit http://store.usgs.gov

Any use of trade, firm, or product names is for descriptive purposes only and does not imply endorsement by the U.S. Government.

Although this information product, for the most part, is in the public domain, it also may contain copyrighted materials as noted in the text. Permission to reproduce copyrighted items must be secured from the copyright owner.

Suggested citation:

Measures, L.N., 2014, Anisakiosis and pseudoterranovosis: Reston, Va., U.S. Geological Survey Circular 1393, 34 p., 2 appendixes, $h$ ttp://dx.doi.org/10.3133/cir1393.

Library of Congress Cataloging-in-Publication Data

Measures, Lena N., 1950-, author.

Anisakiosis and pseudoterranovosis / by Lena N. Measures.

p. ; cm. -- (Circular; 1393)

At head of title: National Wildlife Health Center.

Includes bibliographical references and index.

ISBN 978-1-4113-3809-8 (alk. paper)

I. National Wildlife Health Center (U.S. : 1993-) II. Title. III. Series: U.S. Geological Survey circular ; 1393.

[DNLM: 1. Anisakiasis--epidemiology. 2. Ascaridida Infections--epidemiology. WC 870]

RC840.A56

$616.9^{\prime} 654--d c 23$

2014032432 


\title{
Foreword
}

\author{
C. van Riper, III, R. C. Abbott, C. Bunck, and M. Friend \\ "Make no mistake, they are connected, these disease outbreaks coming one after \\ another. And they are not simply happening to us; they represent the unintended \\ results of things we are doing. They reflect the convergence of two forms of crisis on \\ our planet. The first crisis is ecological, the second is medical."
}

\section{David Quammen, Spillover}

The emergence of many new (and older) zoonotic diseases in humans in recent years is largely a result of our densely populated, highly mobilized, and environmentally disrupted world that is experiencing rapid climatic changes. The number of zoonotic diseases detected has been of unprecedented scope relative to geographic areas of occurrence, wildlife species affected, and the variety of pathogens involved (Daszak and others, 2000; Friend, 2006). As towns and cities expand, the wildland-urban interface broadens and human associations with wildlife become increasingly frequent. With geographic distance and isolation no longer serving as meaningful barriers, opportunities for once isolated diseases to spread have never been greater. Consequently, and especially as a result of rapid warming in the polar region due to climate change, zoonotic diseases such as anisakiosis and pseudoterranovosis will begin to appear more frequently in northern latitude animal and human populations.

Human infections with "whale worm" or "seal worm" are becoming more common with the popularity of eating raw fish. People are accidentally infected by larval stages of the nematodes in marine fish or squid that are raw, poorly cooked, cold-smoked, lightly salted, or marinated. It is safe to assume that both these parasites can be found wherever suitable hosts occur and favorable environmental conditions permit. Thus, humans consuming improperly prepared infected wild fish or squid are at risk, especially those with cultural culinary practices that do not kill larvae. And as gastronomic trends spread around the globe, foodborne zoonoses, such as anisakiosis and pseudoterranovosis, will occur in new locations.

Dealing with emerging zoonotic diseases requires the ability to recognize pathogens when they first appear and to act quickly and appropriately. Because outbreaks often are evident in nonhuman components of the environment before humans are affected, understanding our environment and associated 'sentinel' wildlife is a prerequisite to protecting human health. Through understanding infection levels in wildlife populations, we will be better able to predict future human infection levels. This report, seventh in the series of U.S. Geological Survey Circulars on zoonotic diseases, will help us to better understand the routes of anisakiosis and pseudoterranovosis infections and how best to adequately monitor these zoonotic diseases.

Daszak, P., Cunningham, A.A., and Hyatt, A.D., 2000, Emerging infectious diseases of wildlife-Threats to biodiversity and human health: Science, v. 287, p. 443-449.

Friend, M., 2006, Disease emergence and reemergence: The wildlife-human connection: Reston, Va., U.S. Geological Survey Circular 1285, 388 p.

Quammen, D., 2012, Spillover: animal infections and the next human pandemic: New York, N.Y., W.W. Norton and Co., Inc., p. 39. 



\section{Contents}

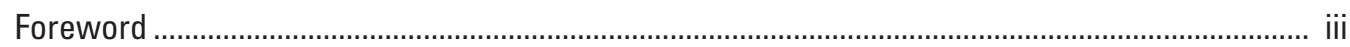

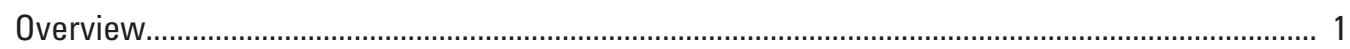

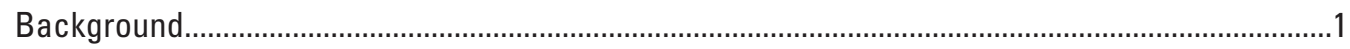

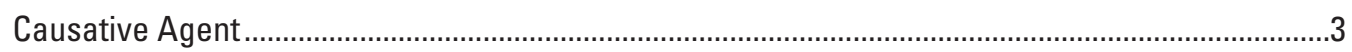

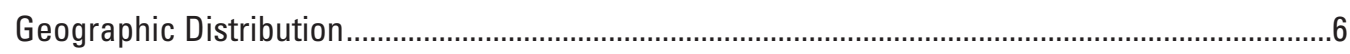

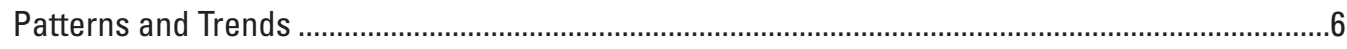

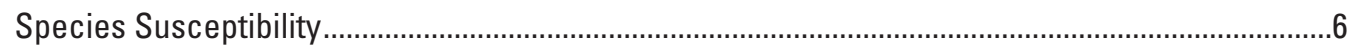

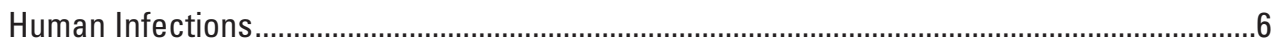

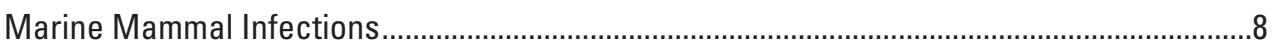

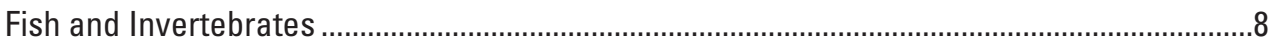

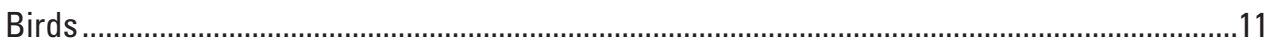

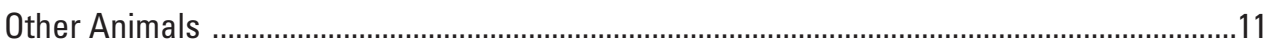

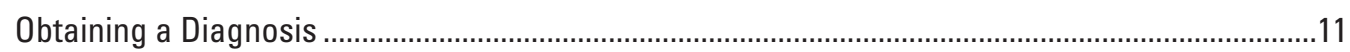

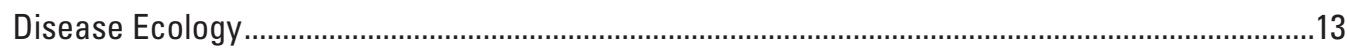

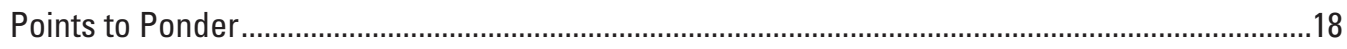

Disease Prevention and Control...................................................................................................18

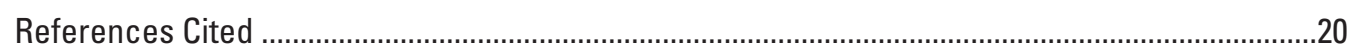

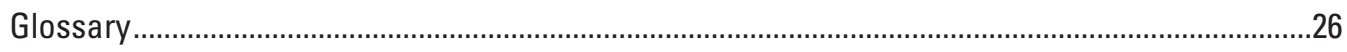

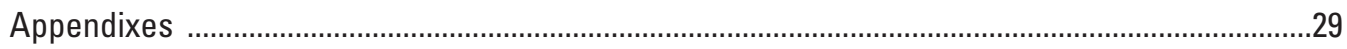

\section{Topic Highlight Boxes}

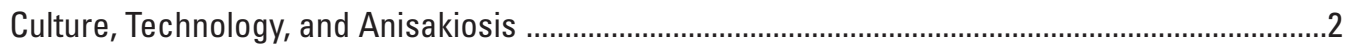

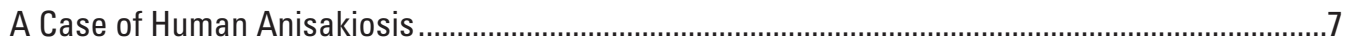

Migration of Adult Hysterothylacium aduncum in Atlantic Cod After Host Death ..........................16

Commercial Candling of Fish Fillets to Visualize and Extract Pseudoterranova decipiens ............17

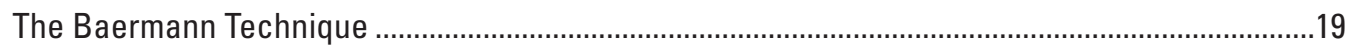

\section{Figures}

1. Photo showing adult Anisakis simplex in the stomach of a pilot whale ...................................

2. Photo showing adult Pseudoterranova decipiens in the stomach of a grey seal......................9

3. Photo showing red vent syndrome in Atlantic salmon ..............................................................10

4. Anatomical drawing of key morphological features of anisakid larvae removed from fish: A, Anisakis, B, Contracaecum/Phocascaris; C, Pseudoterranova ..............................12

5. Diagram showing the life cycle of Anisakis simplex...........................................................13

6. Photo showing larval Anisakis sp. (arrows) in the abdominal cavity of an Atlantic herring .......................................................................................................... 14

7. Diagram showing the life cycle of Pseudoterranova decipiens ...........................................15

8. Photo showing larval Pseudoterranova sp. in muscle of an American plaice ...........................15 


\section{Tables}

1. Taxonomic classification of the parasites causing anisakiosis and pseudoterranovosis

2. Timeline of events in the discovery of human anisakidosis .........................................................2

3. Marine mammal hosts and geographic range of Anisakis spp. .................................................4

4. Marine mammal hosts and geographic range of Pseudoterranova spp. ..................................5

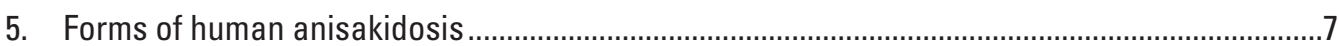

6. Methods to reduce risk of infection by anisakid larvae for consumers of fish .......................18

\section{Conversion Factors and Abbreviations}

International System of Units to Inch/pound

\begin{tabular}{lcl}
\hline \multicolumn{1}{r}{ Multiply } & By & \multicolumn{1}{c}{ To obtain } \\
\hline & Length & \\
\hline centimeter $(\mathrm{cm})$ & 0.3937 & inch (in.) \\
millimeter $(\mathrm{mm})$ & 0.03937 & inch (in.) \\
\hline & Mass & \\
\hline kilogram $(\mathrm{kg})$ & 2.205 & pound avoirdupois (lb) \\
\hline
\end{tabular}

Temperature in degrees Celsius $\left({ }^{\circ} \mathrm{C}\right)$ may be converted to degrees Fahrenheit $\left({ }^{\circ} \mathrm{F}\right)$ as follows:

${ }^{\circ} \mathrm{F}=\left(1.8 \times^{\circ} \mathrm{C}\right)+32$

Words shown in bold are defined in the glossary. 


\title{
Anisakiosis and Pseudoterranovosis
}

\author{
By Lena N. Measures ${ }^{1}$
}

\section{Synonyms}

Anisakiasis, whaleworm and herringworm infection, pseudoterranovosis, sealworm, and codworm infection

\section{Overview}

Anisakiosis is a parasitic disease caused by infection with larval nematodes or roundworms of the taxonomic genus Anisakis, which belong to the family, Anisakidae, subfamily Anisakinae. Anisakiosis is a zoonotic disease, meaning it is transmissible between animals and humans and vice versa. Other related roundworms, such as Pseudoterranova and Contracaecum, may cause similar, but less frequently reported, diseases (pseudoterranovosis, contracaecosis). The terms anisakidosis (anisakidiasis), referring to disease caused by members of the family, and anisakinosis (anisakiniasis), referring to disease caused by members of the subfamily, may be encountered in technical literature (Kassai and others, 1988) when specimens cannot be identified to genus. Because most cases of anisakidosis in humans are due to larval Anisakis spp. and, to a lesser extent, larval Pseudoterranova spp., further discussion will be limited to these anisakids (table 1).

The life cycles of Anisakis spp., commonly called whaleworm (previously known as herringworm), and Pseudoterranova spp., commonly called sealworm (previously known as codworm), are complex and involve three marine hosts (invertebrates, fish, and marine mammals). Whales, dolphins, or porpoises (collectively known as cetaceans) are the definitive hosts in which Anisakis spp. become sexually mature, and seals, sea lions, or walrus (collectively known as pinnipeds) are the definitive hosts of Pseudoterranova spp. These zoonotic parasites have medical and economic importance and can result in considerable costs to the fishing industry. Humans are accidentally infected by consuming raw, poorly cooked, cold smoked, lightly salted, or marinated marine fish or squid, the intermediate hosts infected with larval stages. Human infections are becoming more common with the popularity of eating raw fish as well as improved medical diagnostics. Infections are rarely diagnosed correctly in North America, which often leads to surgical intervention. Symptoms in humans may involve nausea, vomiting, and severe stomach (gastric) or abdominal pain.

\footnotetext{
${ }^{1}$ Maurice Lamontagne Institute, Fisheries and Oceans Canada.
}

Table 1. Taxonomic classification of the parasites causing anisakiosis and pseudoterranovosis.

\begin{tabular}{|c|c|c|}
\hline Classification & \multicolumn{2}{|c|}{ Designation } \\
\hline Kingdom & \multicolumn{2}{|c|}{ Animalia } \\
\hline Phylum & \multicolumn{2}{|c|}{ Nematoda } \\
\hline Class & \multicolumn{2}{|c|}{ Secernentea } \\
\hline Order & \multicolumn{2}{|c|}{ Ascardida } \\
\hline Family & \multicolumn{2}{|c|}{ Anisakidae } \\
\hline Subfamily & \multicolumn{2}{|c|}{ Anisakinae } \\
\hline Genus & Anisakis & Pseudoterranova \\
\hline \multirow[t]{10}{*}{ Species } & $\begin{array}{l}\text { simplex } \\
\quad \text { sensu stricto }\end{array}$ & $\begin{array}{l}\text { decipiens } \\
\quad \text { sensu stricto }\end{array}$ \\
\hline & berlandi & krabbei \\
\hline & pegreffi & bulbosa \\
\hline & typica & azarasi \\
\hline & physeteris & cattani \\
\hline & ziphidarum & decipiens $E$ \\
\hline & paggiae & kogiae \\
\hline & brevispiculata & ceticola \\
\hline & nascettii & \\
\hline & schupakovi & \\
\hline
\end{tabular}

\section{Background}

Although the genus of Anisakis was established in 1845 by Félix Dujardin to group some parasitic nematodes known from the stomach and intestine of marine mammals, it took more than 100 years until the first human infections were described in Holland and Japan (table 2). Since then, thousands of people in Japan have contracted anisakiosis.

In the Western hemisphere, infections caused by larvae of the Anisakidae family or similar larvae were reported from Inuit in Greenland as early as 1867 (Martin, 1921 cited in Jackson, 1975) and Alaska (Hitchcock, 1950). Since then many human cases of "anisakiasis" have been reported from Canada and the United States, but few cases of anisakiosis have been confirmed by identification of specimens as Anisakis spp. (Smith, 1999; Couture and others, 2003). Most identified specimens from human cases in the Western Hemisphere are reported as Pseudoterranova spp., thus infections are called pseudoterranovosis (Amin and others, 2000). 
Table 2. Timeline of events in the discovery of human anisakidosis.

1845 Gcnus of Aizisakis is established by Félix Dujardin to group neıraiodts causing lesions in the stomachs of cetaceans.

1867 Ascarid-like or anisakine infections are reported from Inuit people in Greenland (Martin, 1921 cited in Jackson, 1975).

Early Gastrointestinal lesions in humans, with small

1940s Ascaris-like larvae in a few cases are documented in Japanese medical journals (Oshima, 1972).

1949 Ascarid-like or anisakine infections are reported from Inuit people in Alaska (Hitchcock, 1950).

1955 The first human cases of anisakiosis are observed in Holland (van Thiel and others, 1960; Rodenburg and Wielinga, 1960; Kuipers and others, 1960).

1955-67 Almost 150 cases of human anisakiosis are documented in Holland.

1965 The first human case of anisakiosis in Japan is described (Asami and others, 1965).
Pseudoterranovosis has been reported in Japan, but it is less common than anisakiosis (Ishikura and others, 1992). Three hundred thirty-five human cases of pseudoterranovosis in Japan and 19 in other countries, including the United States, Canada, Greenland, Chile, the United Kingdom, and Korea, have been reported (Ishikura and others, 1992). Pseudoterranovosis has been reported frequently in northern Japan (Hokkaido) and attributed to dietary differences compared to southern Japan and the presence of populations of pinnipeds, such as sea lions and seals. Recently, pseudoterranovosis has been reported from Mexico and South America (Torres and others, 2007).

For further reading, the bibliographic citations of key publications that address various aspects of anisakiosis and pseudoterranovosis are listed in appendix 2 .

\section{Culture, Technology, and Anisakiosis}

Anisakiosis in a human was first observed in 1955 in Holland (van Thiel and others, 1960; Rodenburg and Wielinga, 1960; Kuipers and others, 1960). Although larval forms of roundworms in the Anisakidae family are common in marine fish, the apparent sudden appearance of anisakiosis in Holland was attributed to changes in fish processing and marketing practices during the early 1950s. Traditionally, fresh-caught herring were eviscerated at sea, but with the advent of refrigeration, onboard ship processing changed to icing whole fish and eviscerating them when ships returned to port, sometimes days later. In addition, so called "green herring," which was lightly salted raw herring, was introduced to the Dutch market and became very popular. These two practices led to larval Anisakis spp. migrating after the death of the fish host from the viscera into the muscles, surviving further inadequate processing and remaining alive for days. Consequently, almost 150 cases of human anisakiosis were documented between 1955 and 1967 in Holland. Dutch parasitologists eventually linked larval nematodes from herring with cases of anisakiosis in humans and finally identified them as Anisakis spp. As a result of these findings, in 1968 Dutch legislation required that fish be frozen within 12 hours of catch at $-20{ }^{\circ} \mathrm{C}$ and kept frozen for 24 hours before further processing (Oshima, 1972). Although cases of anisakiosis fell in Holland after these measures were implemented, anisakiosis still affects fish consumers in Europe. Consumption of gravlax (cured salmon, often dried) in Nordic countries and boquerones (an appetizer of fish, often anchovies, macerated in vinegar) in Spain has been implicated in infections of anisakiosis (Audicana and others, 2002).

Traditionally, the Japanese have consumed raw fish (sashimi) and raw squid (ikasashi) as a delicacy for many years (Ishikura and others, 1992). Gastrointestinal lesions in humans were documented in Japanese medical journals in the early 1940s (Oshima, 1972). In a few cases small "Ascaris-like" larvae were reported, but it was not until 1965, after the Dutch anisakiosis cases were published, that the first authoritative case of human anisakiosis in Japan was described (Asami and others, 1965). Since then thousands of cases have been reported in Japan (Oshima, 1972; Ishikura and others, 1992; Sugimachi and others, 1985;

Nagasawa, 1993). 


\section{Causative Agent}

Although larval anisakines were known in marine fish for a long time (Myers, 1976), it was not until the mid-1800s that nematodes causing lesions in the stomachs of cetaceans were grouped under the genus name Anisakis by Félix Dujardin. Initially, larval nematodes from the first human cases of anisakiosis in Holland were identified as Eustoma rotundatum, later changed to Anisakis marina, and then finally changed to Anisakis simplex.

The Anisakis genus, which at one time included 21 species, was reviewed in the 1960s, and 3 valid species were accepted based on studies of the parasite's form and structure (morphology): Anisakis simplex, Anisakis typica, and Anisakis physeteris (Davey, 1971). Over the past three decades, the number of species has increased based on examination of material from intermediate and definitive hosts and the use of molecular and genetic methodologies (see Mattiucci and Nascetti, 2008, for review). Anisakis simplex sensu lato broadly refers to a group of three sibling species, including Anisakis simplex sensu stricto specifically, Anisakis berlandi, and Anisakis pegreffi. In addition to A. typica and A. physeteris, at least five other nominal species have been described (table 1). It is very likely that further research will reveal new species in cetaceans not yet examined for parasites and expand the host range of known species of Anisakis (table 3).
Parasitic worms from the stomachs of seals were first described by Harald Krabbe in 1878 as Ascaris decipiens. The species was then taxonomically moved into and out of the genera, Porrocaeum, Terranova, Phocanema, and finally into Pseudoterranova. Recent research using molecular and genetic methodologies (see Paggi and others, 1991; Brattey and Davidson, 1996; Paggi and others, 2000; Zhu and others, 2002; Mattiucci and Nascetti, 2008 for reviews) has also determined that Pseudoterranova decipiens sensu lato consists of at least six sibling species: Pseudoterranova decipiens sensu stricto, P. krabbei, P. bulbosa, P. azarasi, P. cattani, and $P$. decipiens $\mathrm{E}$ (not given a name at present). Two other species were described, $P$. kogiae in the pygmy sperm whale and $P$. ceticola in the dwarf sperm whale (Johnston and Mawson, 1939; Deardorff and Overstreet, 1981) (table 4). The definitive host range of known species of Pseudoterranova is shown in table 4, but future work may identify new pinniped hosts or new species of Pseudoterranova.

Some species of Anisakis and Pseudoterranova are found in the same geographic area and infect the same individual definitive host, indicating inbreeding, which should not occur if a species is biologically valid. In a few of these cases, hybrids of species of Anisakis and hybrids of species of Pseudoterranova are found, suggesting the taxonomic status of these species is still evolving (Paggi and others, 1991; Abollo and others, 2003; Martín-Sánchez and others, 2005; Mattiucci and others 2004; Mattiucci and others, 2014).
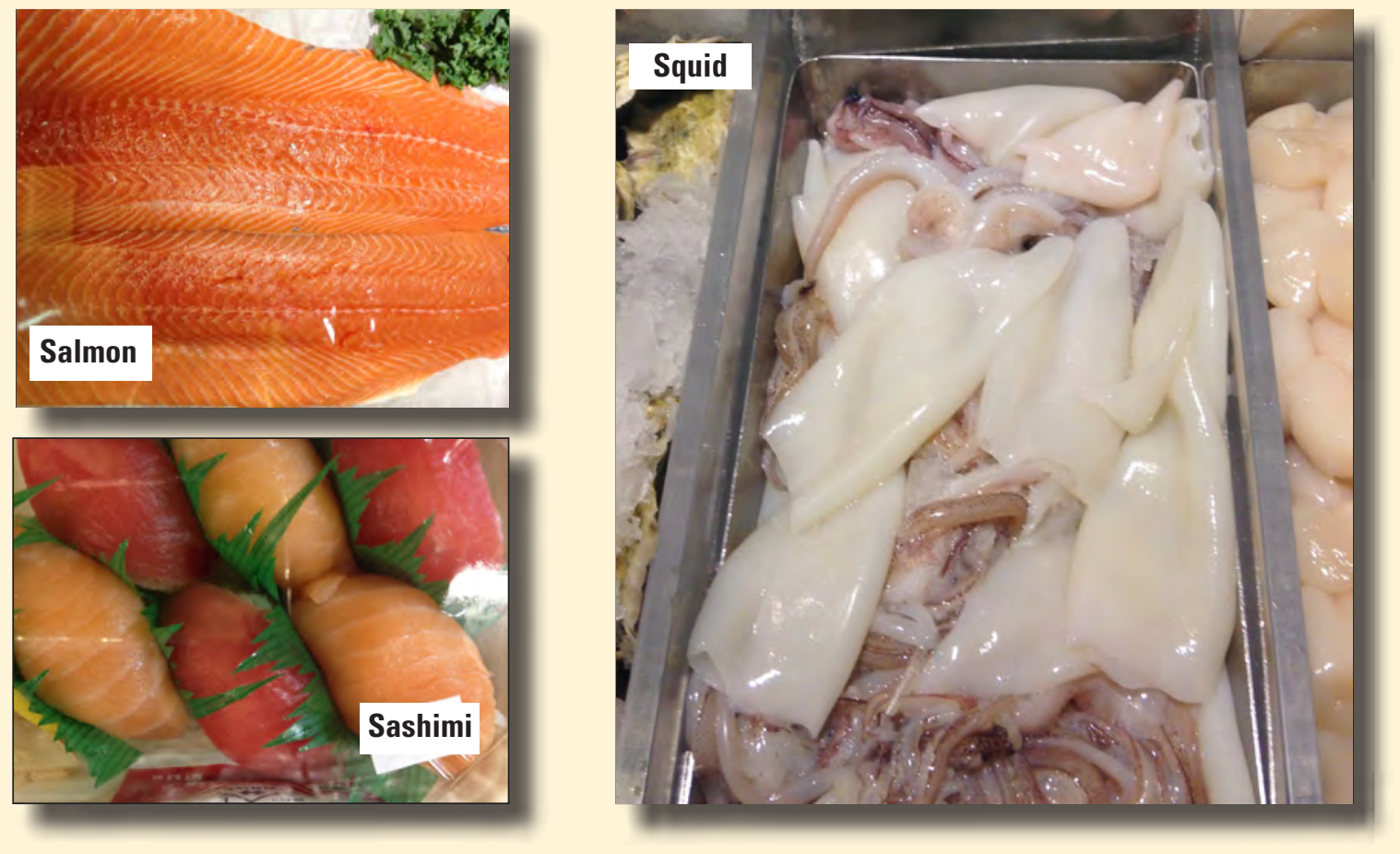
Table 3. Marine mammal hosts and geographic range of Anisakis spp.

[Species listed are those identified and described based on molecular identification except where indicated. See D`Amelio and others (2000); Mattiucci and Nascetti (2008); Mattiucci and others (2009); Iniguez and others (2009); Colón-Llavina and others (2009); Mattiucci and others (2014)]

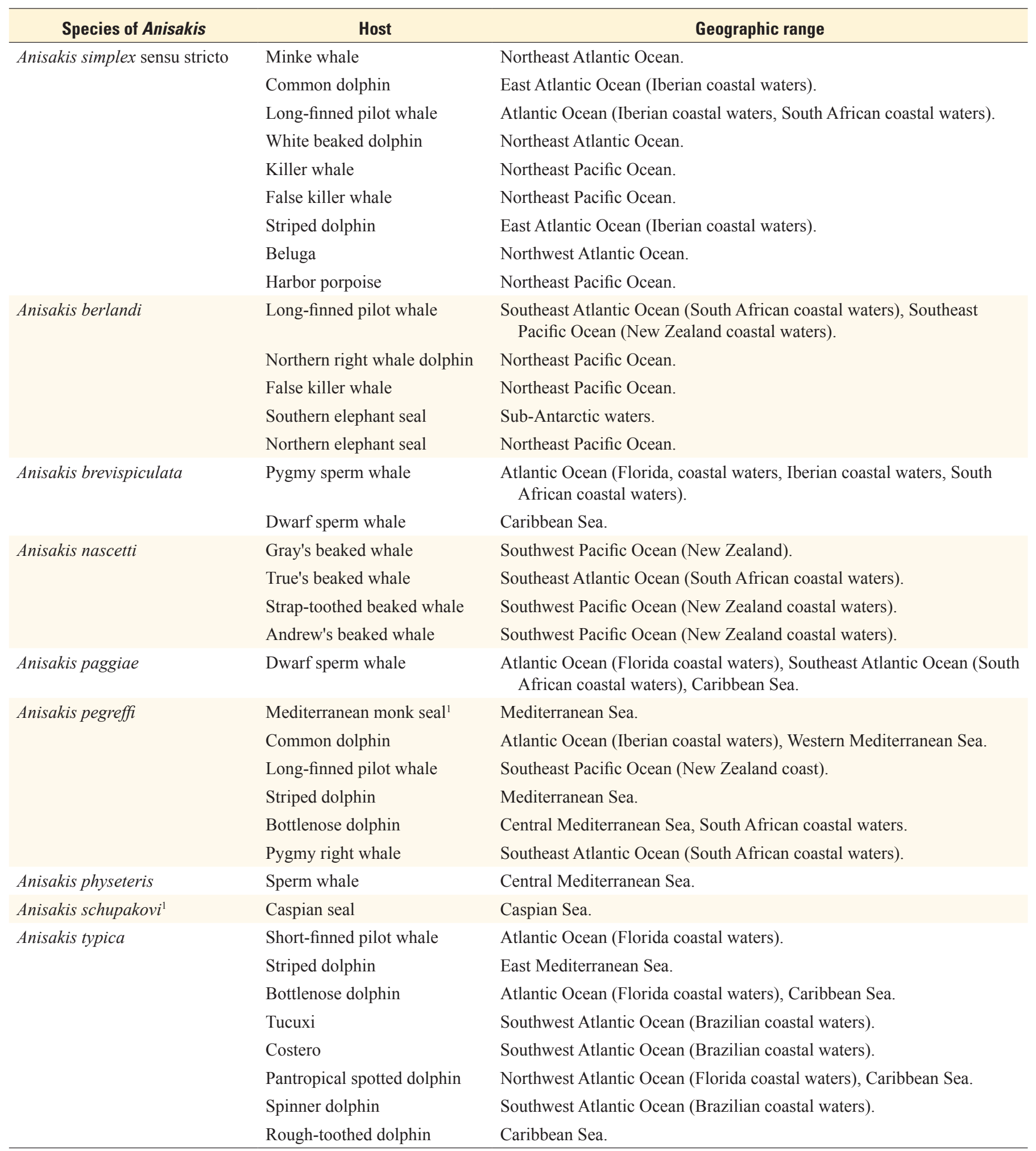


Table 3. Marine mammal hosts and geographic range of Anisakis spp.

[Species listed are those identified and described based on molecular identification except where indicated. See D`Amelio and others (2000); Mattiucci and Nascetti (2008); Mattiucci and others (2009); Iniguez and others (2009); Colón-Llavina and others (2009); Mattiucci and others (2014)]

\begin{tabular}{lll}
\hline \multicolumn{1}{c}{ Species of Anisakis } & \multicolumn{1}{c}{ Host } & \multicolumn{1}{c}{ Geographic range } \\
\hline Anisakis ziphidarum & Strap-toothed beaked whale & Southeast Atlantic Ocean (South African coastal waters). \\
& Blainville's beaked whale & Southeast Atlantic Ocean (South African coastal waters). \\
& Gervais' beaked whale & Caribbean Sea. \\
& Cuvier's beaked whale & Central Mediterranean Sea, South African coastal waters, Caribbean Sea. \\
& Gray's beaked whale & Southeast Atlantic Ocean (South African coastal waters). \\
& True's beaked whale & Southeast Atlantic Ocean (South African coastal waters). \\
& Andrew's beaked whale & Southwest Pacific Ocean (New Zealand coastal waters). \\
\hline
\end{tabular}

${ }^{1}$ Based on morphology only.

Table 4. Marine mammal hosts and geographic range of Pseudoterranova spp.

[Species listed are those identified and described based on molecular identification except where indicated. See Johnston and Mawson (1939); Deardorff and Overstreet (1981); Nadler and others (2005); Mattiucci and Nascetti (2008)]]

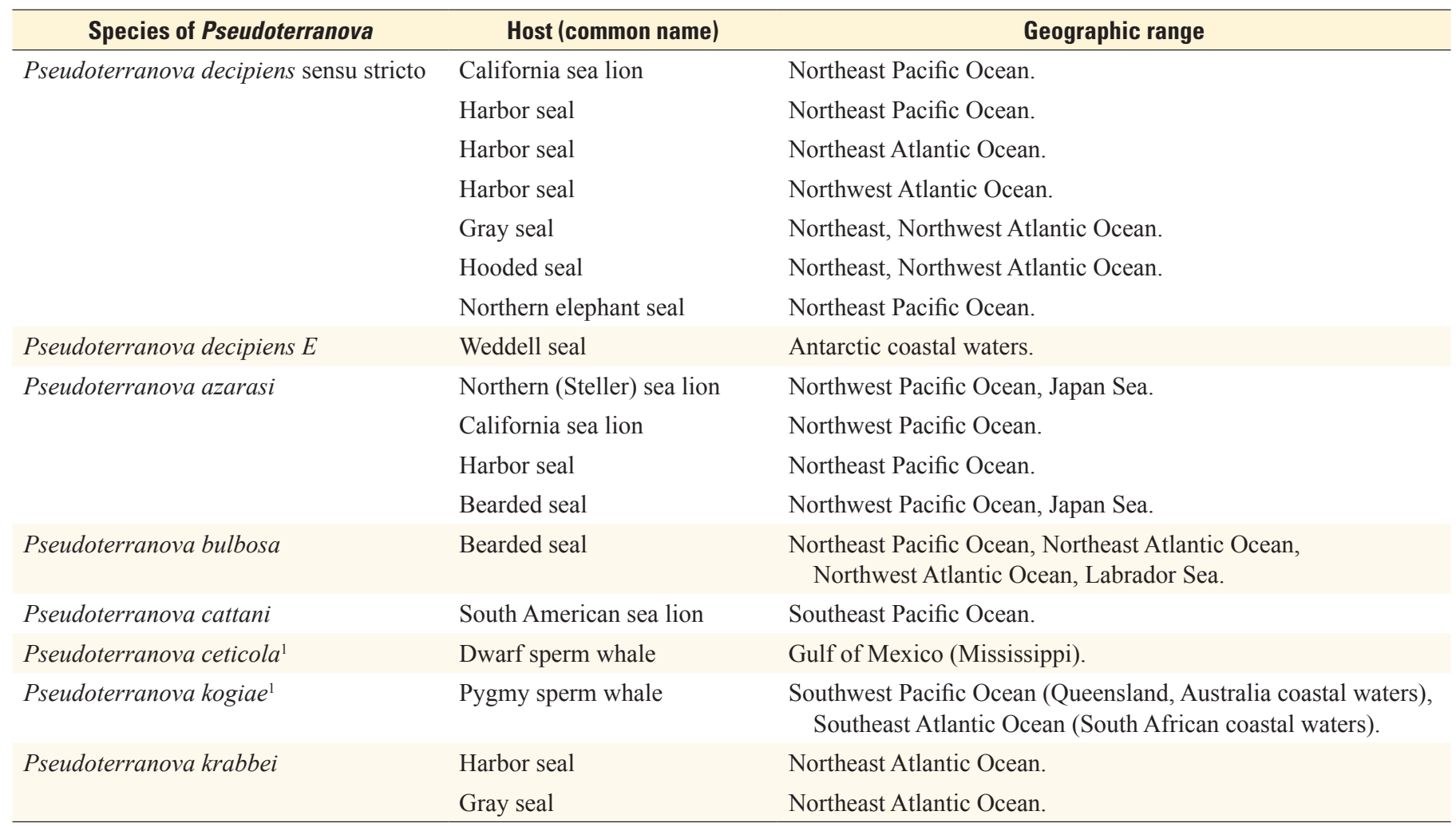

${ }^{1}$ Based on morphology only. 


\section{Geographic Distribution}

Species of Anisakis and Pseudoterranova are widely distributed in the marine environment, but most reports are from the Northern Hemisphere and probably reflect research interest. Most human cases of anisakiosis and pseudoterranovosis are from Japan, Europe, and North America; however, recent work in the Southern Hemisphere reports these parasites in various intermediate and definitive hosts as well as in humans (Palm, 1999; Mercado and others, 2001; Berón-Vera and others, 2007; Torres and others, 2007). The reported low prevalence or absence of Anisakis spp. in Antarctic fish may be related to the distribution of definitive hosts and environmental conditions such as temperature (Measures, 1996; Klimpel and others, 2010). It is safe to assume that both Anisakis and Pseudoterranova can be found wherever suitable hosts live and favorable environmental conditions permit. Consequently, humans who consume improperly prepared infected wild fish or squid are at risk, especially people with cultural culinary practices that do not kill larvae.

\section{Patterns and Trends}

Although cases of anisakiosis fell in Holland after legislative measures were implemented to protect consumers of fish, anisakiosis is still reported in Europe (Smith, 1999; Eskesen and others, 2001; Johansson and others, 2001; Alonso-Gómez and others, 2004), numbering approximately 500 human cases to date (Audicana and others, 2002). In Japan, more than 2,000 cases are reported by physicians annually (Kagei and others, 1995). In Canada and the United States, some 50 cases of "anisakiasis" have been reported (McKerrow and others, 1988), although the total may now be approaching 300 (Amin and others, 2000). An increasing number of cases are reported from South America (Mercado and others, 2001; Torres and others, 2007). A small number of cases of anisakiosis are documented from native peoples in the north (Alaska, Canada, Greenland), but cases are probably under-reported and misdiagnosed (Food Safety Network, 2009; Bhat and Cleland, 2010; Jenkins and others, 2013).

Increased reports of anisakidosis in Japan since 1972 have been attributed to improved medical diagnostic methods such as gastroendoscopy and radiology, in addition to increasing populations of marine mammals, particularly pinnipeds in northern Japan (Oshima, 1987). In addition, associations between the prevalence of sealworm infections in commercial fish and seal populations are not fully understood (McClelland, 2002). Other abiotic factors, such as water temperature, are important in transmission (McClelland, 1982, 1990, 1995; Measures, 1996; McClelland and Martell, 2001; McClelland, 2002).

When "sushi bars" became popular in North America during the mid-1970s, cases of anisakidosis appeared, but pseudoterranovosis was reported more commonly than anisakiosis (Little and MacPhail, 1972; Little and Most, 1973; Kates and others, 1973; Chitwood, 1975; Lichtenfels and Brancato, 1987; Margolis, 1977; Kliks, 1983; Desowitz, 1986; Oshima, 1987; Amin and others, 2000). Eleven cases of anisakiosis and 14 cases of pseudoterranovosis were reported in North America between 1974-87 (Oshima, 1987). The large populations of pinniped definitive hosts of the parasites on the Atlantic and Pacific coasts of North America, as well as cultural dietary differences, may explain some of these cases. Dozens of cases of pseudoterranovosis due to consumption of raw fish (ceviche, also spelled cebiche) have been reported from Chile, Brazil, and Mexico (Torres and others, 2007). Many cases, however, probably go unreported or are incorrectly diagnosed. The ease of removing Pseudoterranova spp. from the person's stomach by endoscopy for identification and the frequency by which the worm is coughed or spit out by the human consumer probably accounts for the increasing number of reports of pseudoterranovosis. Many sealworms are removed during commercial processing of fish or are seen by the consumer before consumption, thus many infections are likely avoided. In Atlantic Canada it has been estimated that annual costs to the fishing industry to remove sealworms and losses due to reduced value of fish products are \$27-50 million Canadian dollars (see McClelland, 2002).

Increasing populations of whales and seals, changes in their distribution or that of their prey, and enhanced parasite transmission due to favorable environmental factors, combined with the growing popularity of sushi, sashimi, and ceviche, are expected to raise the risk of human exposure to anisakids and the frequency of diagnosed anisakidosis (due to improved medical diagnostics).

\section{Species Susceptibility}

Humans and other nondefinitive hosts are accidentally infected by ingesting infected fish or invertebrates. Because Anisakis spp. and Pseudoterranova spp. do not mature and reproduce in humans or other nondefinitive hosts, these hosts may be considered dead-end hosts even though they are susceptible to infection.

\section{Human Infections}

Four forms of human anisakidosis (anisakiosis and pseudoterranovosis) have been described (Smith, 1999) (table 5). The most commonly reported form is gastric or intestinal anisakidosis in which larvae penetrate the gastrointestinal tract, causing severe damage, pain, and discomfort.

The least invasive of these forms is transient luminal anisakidosis, in which larvae do not penetrate tissues but may remain in the open spaces (lumen) of the gastrointestinal tract for some time, causing mild, temporary discomfort. These mild cases, while not uncommon, typically are caused by 


\section{A Case of Human Anisakiosis}

A man purchased a fresh wild salmon from a local grocery store. The salmon had been caught in the Pacific Ocean near the coast of British Columbia, Canada, gutted, and shipped whole on ice by air to Québec, Canada where the man lived. He consumed some raw salmon while cutting fillets to make marinated salmon. Within 24 hours, he experienced constipation, nausea, and acute abdominal pain, and after 2 days he went to a hospital emergency clinic. Blood samples were taken and $\mathrm{x}$-rays and CT scans performed. Tests revealed he had a slightly above normal number of eosinophils, a type of white blood cell sometimes associated with parasitic infections, and distension and thickening of part of the wall of the small intestine. The man was diagnosed with acute abdominal syndrome, and surgery was performed. The surgeon removed a 15-centimeter $(\mathrm{cm})$ section of thickened small intestine (figure). The man was discharged from the hospital 6 days after surgery. Laboratory analysis of the resected intestine revealed the presence of minute abscesses (arrows) containing sections of a nematode, later identified as a third-stage larval Anisakis spp. This human infection is typical of intestinal anisakiosis. Refer to Couture and others (2003) for further details on this case.

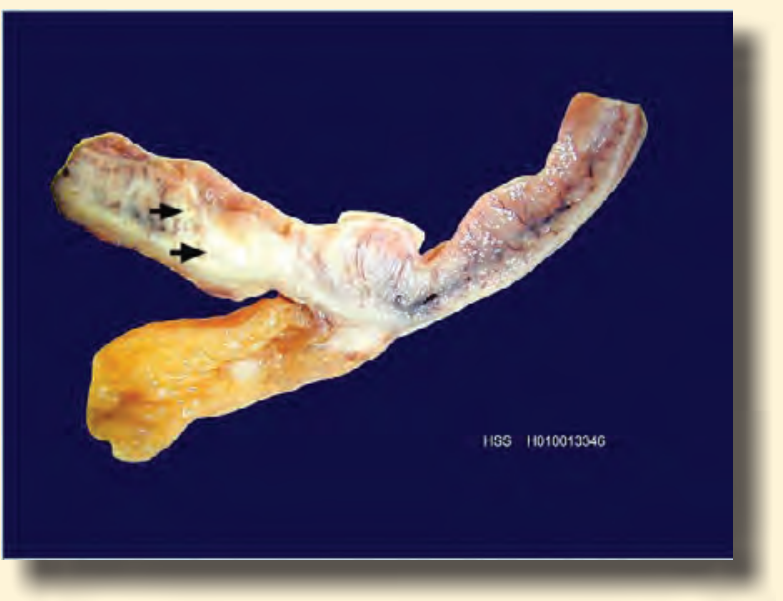

Section of thickened small intestine removed during surgery. The arrows point to minute abscesses containing sections of third-stage larval Anisakis spp. (Photo by Dr. Christian Couture, Hôpital Laval)

Table 5. Forms of human anisakidosis.

\begin{tabular}{|c|c|c|c|c|}
\hline Form & $\begin{array}{c}\text { Relative } \\
\text { occurrence }\end{array}$ & Targeted location & $\begin{array}{c}\text { Tissue } \\
\text { penetration }\end{array}$ & $\begin{array}{c}\text { Degree of } \\
\text { disease effects }\end{array}$ \\
\hline Gastric or intestinal & Most common & Gastrointestinal tract & Yes & Mild to severe. \\
\hline $\begin{array}{l}\text { Outside of the } \\
\text { gastrointestinal tract }\end{array}$ & Relatively rare & $\begin{array}{l}\text { Penetrates the wall of the gastrointes- } \\
\text { tinal tract and enters the body cavity }\end{array}$ & Yes & Severe. \\
\hline $\begin{array}{l}\text { Mouth and pharynx } \\
\text { (throat) }\end{array}$ & Rare & Mouth and pharynx cavity & Yes & Mild. \\
\hline Transient luminal & Common & $\begin{array}{l}\text { Inner or open space of the gastrointes- } \\
\text { tinal tract }\end{array}$ & No & $\begin{array}{l}\text { No symptoms to } \\
\text { mild. }\end{array}$ \\
\hline
\end{tabular}

Pseudoterranova spp. In contrast, Anisakis spp. are generally more invasive and disruptive than Pseudoterranova spp. and are commonly associated with parasites both within and outside of the stomach and intestines. Most human infections are caused by third-stage larvae, rarely fourth-stage larvae (see "Disease Ecology"). Symptoms and observable signs are described in the section "Obtaining a Diagnosis." 


\section{Marine Mammal Infections}

The natural definitive hosts of Anisakis spp. are cetaceans. Based on the literature, at least 53 cetacean species are reported infected with Anisakis spp. Recently, 28 cetacean species infected with Anisakis spp. have had identifications of Anisakis to the species level based on molecular analyses (table 3). Immature Anisakis stages are often found in pinnipeds, where they rarely mature (Brattey and Stenson, 1993; Machida, 1969 cited in Kuramochi and others, 1996; Klimpel and others, 2008). Anisakis schupakovi in the Caspian seal is considered a valid species based on morphology alone (D'Amelio and others, 2000). Similarly, Pseudoterranova spp. are reported as parasites of at least 28 pinniped species, and 11 pinniped species with Pseudoterranova spp. have had identifications of Pseudoterranova to the species level based on molecular analyses (table 4). Immature Pseudoterranova spp. stages are occasionally found in cetaceans and sea otters, where they rarely mature (Measures and others, 1995; Smith, 1999). Two species, $P$. kogiae in pygmy sperm whales and $P$. ceticola in dwarf sperm whales, are known based on morphology alone.

Evidence suggests that some definitive hosts differ in how susceptible they are to the parasites, the number of worms they harbor (intensity of infection), the ability of the parasites to grow and reproduce in them, and their responses to Anisakis spp. or Pseudoterranova spp. For example, based on field data from the North Atlantic Ocean and experimental work, grey seals infected with $P$. decipiens have greater numbers of worms, less intense tissue reaction, greater parasite growth, greater parasite egg production, and higher worm survival than harbor seals infected with P. decipiens (McClelland, 1980a; Aspholm and others, 1995; McClelland, 2002). The numbers of $P$. decipiens within a host are low, and few mature worms are found in harp, hooded, and ringed seals (McClelland, 2002). Some cetaceans such as minke whales and beluga can harbor large numbers of $A$. simplex of considerable size with high egg production, while fewer worms often are observed in porpoises or dolphins that harbor only larvae or small adults with comparatively low egg production (Brattey and Stenson, 1995; Measures and others, 1995, Kuramochi and others, 1996; Simard, 1997; Ugland and others, 2004; Berón-Vera and others, 2008). Infections of anisakids in marine mammals are influenced by the availability of infected intermediate or transport hosts, host diet, host immune and physiological status, whether the host lives in or migrates through inshore or offshore habitats, as well as seasonal and environmental factors.

In the gastrointestinal tract of definitive hosts, anisakids are generally harmless (Stroud and Roff, 1979; McClelland, 1980b; Smith, 1989; Babin and others, 1994; Abollo and others, 1998) even when present in high numbers, but severe damage has been reported in some hosts. Pathologic lesions caused by anisakids in marine mammals were reviewed by Smith (1999). Generally, anisakids provoke gastric craterlike ulcers or erosions where they attach to the mucous membranes (mucosa) in clusters of dozens to hundreds (figs. 1, 2).

In cetaceans, Anisakis spp. are found primarily in the first chamber of the stomach (forestomach), sometimes in the second chamber (main stomach), and rarely in the third chamber (pyloric stomach). Worms in the intestine are indicative of aberrant migrations, failed infections, or aging of the worm. Inflammation of the stomach (gastritis) and the intestine (enteritis) due to Anisakis spp. and Pseudoterranova spp. have been reported. In extreme cases, worms may penetrate the gut, enter the body cavity, and cause hemorrhage, secondary bacterial infections, inflammation of the covering of the stomach, intestines, and nearby organs (peritonitis), and death (Ridgway and others, 1975; Stroud and Dailey, 1978; Martineau and others, 1988; Baker and Martin, 1992; De Guise and others, 1995; Lair and others, 2014).

In unusual hosts, such as the sea otter, $P$. decipiens (primarily larvae) is associated with stomach ulcers, holes or perforations in the intestines, and death due to peritonitis (Rausch, 1953; Fay and others, 1978 in Smith, 1999). Lesions in the pyloric region of the simple stomach may cause narrowing, physically preventing the movement of food or leading to an abnormal accumulation of blood in the veins (Smith, 1999). Ulceration and gut perforation by parasites such as $A$. simplex can provide portals of entry for viruses or bacteria, some of which may lead to abscesses, systemic infections of the entire body, or possibly other chronic diseases (Martineau and others, 1988; Baker and Martin, 1992; De Guise and others, 1994, 1995; Harper and others, 2002a, 2002b; Lair and others, 2014).

\section{Fish and Invertebrates}

Larval Anisakis spp. have been reported from a variety of naturally infected invertebrate intermediate hosts, mostly crustaceans such as small shrimplike crustaceans (euphausiids and amphipods), crayfish, crabs, lobsters, and shrimp (decapods), and squid and cuttlefish (cephalopods). Larval Pseudoterranova spp. have been reported in amphipods, decapods, and small, shrimplike crustaceans (mysids) (Uspenskaya, 1963; Oshima and others, 1968; Smith, 1971; Nagasawa and Moravec, 1995; Hays and others, 1998; McClelland, 2002). P. decipiens is known from over 75 fish species belonging to 29 families, 10 orders, and 3 classes of fish (McClelland, 2002). Anisakis spp. are reported from a wide range of marine, estuarine, and occasionally freshwater fish (Oshima, 1972; Smith and Wootten, 1978) and occur in approximately 200 species of fish and 25 species of cephalopods worldwide (Klimpel and others, 2004). However, these figures may be inaccurate due to confusion in larval identification (Oshima, 1972; Smith and Wootten, 1978). For example, one report states that one Anisakis "larval type 1" is known from 123 different fish species in Japanese waters (Oshima, 1972), yet another report states that more than 166 species of fish are infected with anisakids in Japanese waters (Ishimura and others, 1992). 


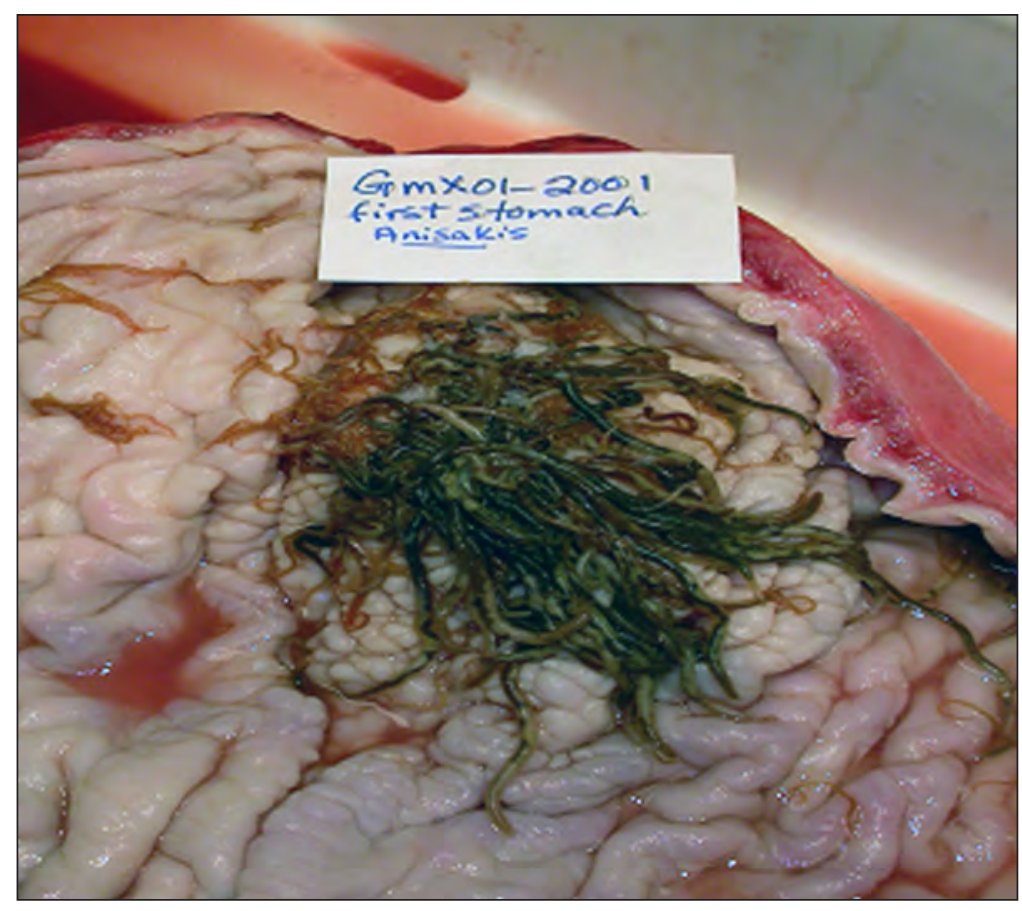

Figure 1. Adult Anisakis simplex in the stomach of a pilot whale.

(Photo by Dr. Lena Measures, Fisheries and Oceans Canada)

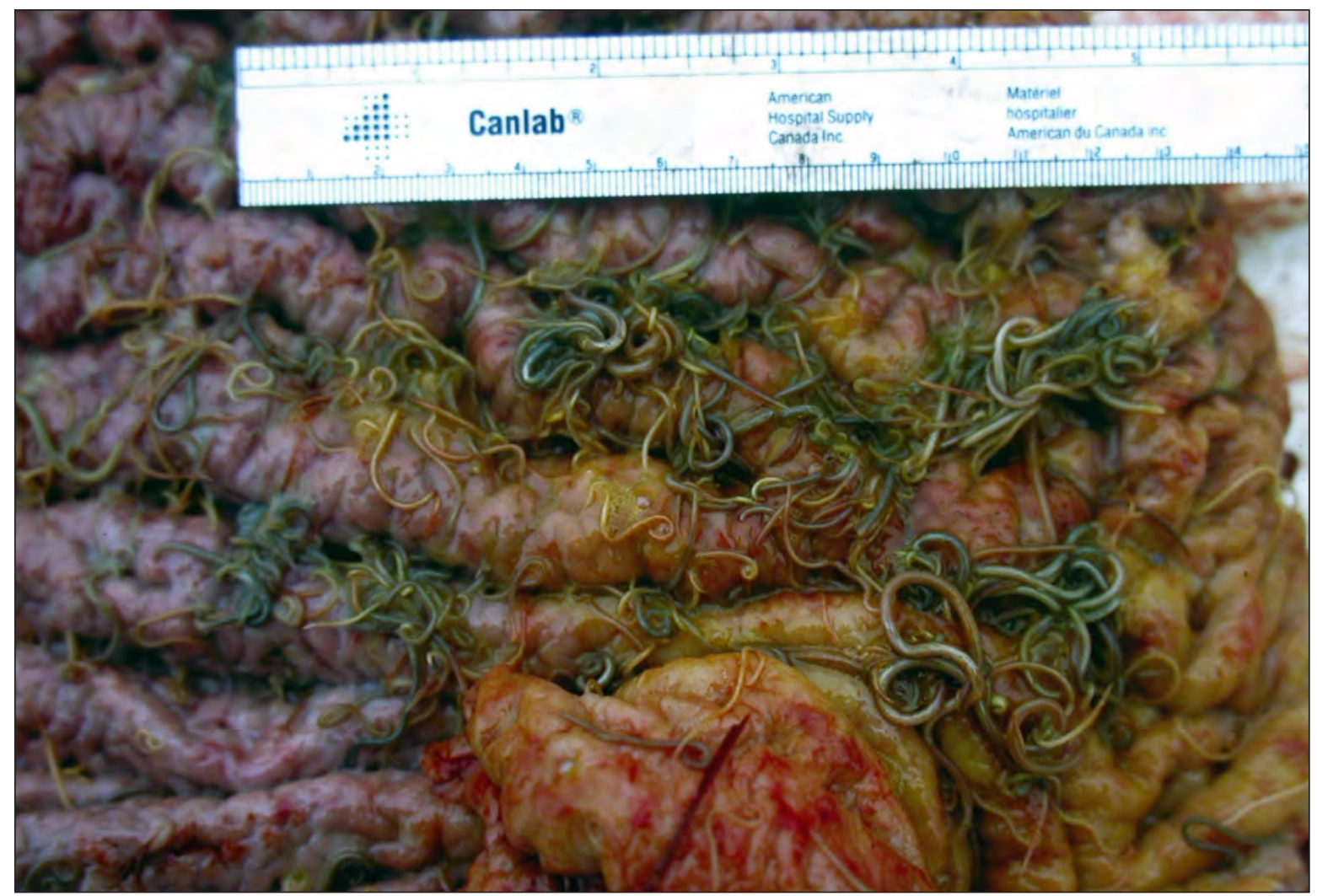

Figure 2. Adult Pseudoterranova decipiens in the stomach of a grey seal. (Photo by Dr. Lena Measures, Fisheries and Oceans Canada) 
Freshwater fish are likely to become infected if they are fed the infected internal organs of marine fish in aquacultural operations or if wild fish such as salmon spend part of their life cycle in salt or estuarine waters where they may acquire infections. Seven cephalopod species can act as transport hosts of $A$. simplex and A. physeteris in Japanese waters (Nagasawa, 1993), and seven cephalopod species have been infected with A. simplex in Spanish waters (Abollo and others, 1998). In cephalopods, Anisakis spp. larvae are found in the internal organs and muscles, and in a few cases, destroy the testes or ovaries of mature squid (Abollo and others, 1998). Although Anisakis spp. and Pseudoterranova spp. are reported from a wide range of fish hosts, it is believed that primarily fish that live in the water column (pelagic fish) are ecologically important for transmitting Anisakis spp. to cetaceans, and fish that live near or on the bottom (benthic fish) are ecologically important for transmitting Pseudoterranova spp. to pinnipeds.

To understand the role of invertebrates and fish in the life cycles of these two anisakids, various experimental infections have been conducted since the early 1950s. For example, 12 different species of fish (marine, anadromous, and freshwater) including Atlantic salmon, brook trout, rainbow smelt, and Atlantic cod were susceptible to experimental infections by $P$. decipiens using experimentally infected amphipod intermediate hosts (McClelland, 1995). In some fish such as rainbow smelt, tissue responses to infections were absent. In other fish, larvae were surrounded or encapsulated by cells of the immune system and eventually killed. Anisakis spp. larvae are rapidly encapsulated in fish, and some larvae die and become hardened by deposited calcium salts (Smith, 1974). Although Anisakis spp. appear to cause few pathologies in fish-unless the liver is heavily infected or there are large numbers of worms - sealworms can kill small fish, particularly when vital organs are damaged by migrating larvae (McClelland, 1995). Experimental evidence indicates that $P$. decipiens infection of some fish species affects their ability to swim and thus escape predators (Sprengel and Lüchtenberg, 1991).

An unusual condition called red-vent syndrome (RVS; fig. 3), associated with heavy infections by larval Anisakis spp. in the skin and muscle tissues of the vent area of wild Atlantic salmon, has been reported in the North Atlantic (Beck and others, 2008) including recently in Canada (Larratt and others, 2013). Lesions appear as small red spots (small hemorrhages) with reddening around the vent in light infections to pronounced swelling, hemorrhage, erosion of the skin's outer layer, loss of scales, and skin inflammation (dermatitis) in severe infections. It is currently unknown why this occurs, but RVS may be an external sign of heavily parasitized fish (Murphy and others, 2010). However, the intensity of larval Anisakis infections in wild Atlantic salmon was only weakly associated with RVS, suggesting other factors may be involved in this syndrome such as immune status, stress, water temperature and timing of infections (Larrat and others, 2013). Increased levels of infections have been observed in adult salmon returning to fresh water to spawn (Murphy and others, 2010). Apparently, after Atlantic salmon spawn, red vent lesions subside somewhat. There is no evidence that RVS causes mortality or prevents salmon from spawning but further research is warranted.

Figure 3. Red-vent syndrome in Atlantic salmon. (Photo by Ministère des resources naturelles et de la faune [Station piscicole de Tadoussac]). 


\section{Birds}

There are a few records of Anisakis spp. larvae in fisheating birds, particularly in Japanese waters. Larval Anisakis spp. have been reported from the herring gull, black-tailed gull, tufted puffin, Swinhoe's storm petrel, Japanese cormorant, and northern fulmar (Riley, 1972; Smith and Wootten, 1978). A single immature adult female Anisakis spp. was reported from the esophagus of a northern fulmar in northern Europe (Riley, 1972). The occurrence of these parasites in fish-eating birds is regarded as accidental.

\section{Other Animals}

Experimentally or inadvertently, frogs, turtles, cats, dogs, rabbits, rats, guinea pigs, domestic pigs, and monkeys were susceptible to infection with Anisakis spp. or Pseudoterranova spp., but results varied (Smith and Wootten, 1978; Smith, 1999). In some cases, worms migrated through various tissues and caused pathologies; in other cases, worms died and were encapsulated by strong tissue responses. Natural infections of a brown bear (Smith and Wootten, 1978; Smith, 1999) and a dog (Kitayama, 1962 in Oshima, 1987) have been reported.

\section{Obtaining a Diagnosis}

Many human cases of anisakiosis and pseudoterranovosis likely go unreported, and probably many worms die or are passed in the feces without causing any symptoms or clinical signs. Diagnosis is difficult, but clinical infections are usually suspected based on symptoms, clinical presentation, and history of recent consumption of improperly prepared seafood. Symptoms in acute cases of gastric anisakidosis include intense upper abdominal pain, nausea, and vomiting within 5 hours of consuming infected fish or squid.

Intestinal anisakidosis has less specific symptoms, but usually the victim experiences low abdominal pain, particularly in the lower right quadrant; nausea; vomiting; fever; diarrhea or constipation; and inapparent blood in the stool, usually within 1-7 days after consuming infected fish or squid. Infections, either gastric or intestinal, may become chronic, and intestinal blockage and tumors (swellings) have been reported (Smith and Wootten, 1978; Smith, 1999). Transient infections with Pseudoterranova spp. are often diagnosed based on the reported symptom of a "tingling" sensation in the throat or mouth or mild abdominal discomfort, and the worms are vomited or coughed up by the patient days to weeks after ingestion (Smith, 1999).
In clinical cases of gastric infection, Pseudoterranova spp. may be diagnosed using gastroendoscopy, whereby a fiberscopic tube equipped with a small camera and forceps is passed through the person's mouth into the stomach to observe the surface of the mucous membranes (Oshima, 1987). Worms can then be removed by using fine biopsy forceps. The same method can be used for gastric infections of Anisakis spp. (Bhat and Cleland, 2010), but not for most intestinal infections due to the physical limit of endoscopy. Fifty-six larval Anisakis spp. were removed by gastroendoscopy from the stomach of a Japanese patient who had prepared her own sashimi (Kagei and Isogaki, 1992). Other medical imaging such as radiology, computed tomography $(\mathrm{CT})$ scans, and abdominal ultrasound may help in diagnoses (Oshima, 1987; Couture and others, 2003).

Blood and blood serum tests such as enzyme-linked immunosorbent assay (ELISA) have been used to detect specific immunoglobulin $\mathbf{E}$ (IgE) antibodies to $A$. simplex (Lorenzo and others, 2000; Valiñas and others, 2001) in blood samples. Histological analysis of biopsied lesions caused by Anisakis spp. or Pseudoterranova spp. attaching to the gastrointestinal wall usually contain eosinophils, a type of white blood cell indicative of parasitic infection. Severe allergic reactions such as dermatitis, subcutaneous swelling, rashes, throat swelling, and low blood pressure, particularly in response to A. simplex, have been reported in acute cases, especially in Spain where more than 150 cases have been reported since 1995 (Audicana and others, 2002). In these cases, specific IgE and skin prick tests have been used in diagnosing allergic reactions to $A$. simplex, but acute parasitic infections and allergies are still under investigation (AlonsoGómez and others, 2004; Reddy and Fried, 2008).

Where clinical infections are rarely encountered by the medical profession, such as in North America and Europe, infections may be misdiagnosed as gastrointestinal cancer, ulcers, obstruction or inflammation such as Crohn's disease, appendicitis, and acute abdominal syndrome. Consequently, abdominal surgery is often performed. It is during surgery that worms, often alive, may be found (Clavel and others, 1993), and usually affected tissues are removed. Histological, morphological, and molecular analyses can be used to identify the cause of tissue inflammation as well as identify the genus, and sometimes the species, of recovered worms (Maejima and others, 1992; Eskesen and others, 2001; Couture and others, 2003; Mattiucci and Nascetti, 2008). Identification of larval Anisakis spp. and Pseudoterranova spp. is based principally on morphology of the digestive system of the worm studied using light microscopy (fig. 4). 
A. Head-Anisakis

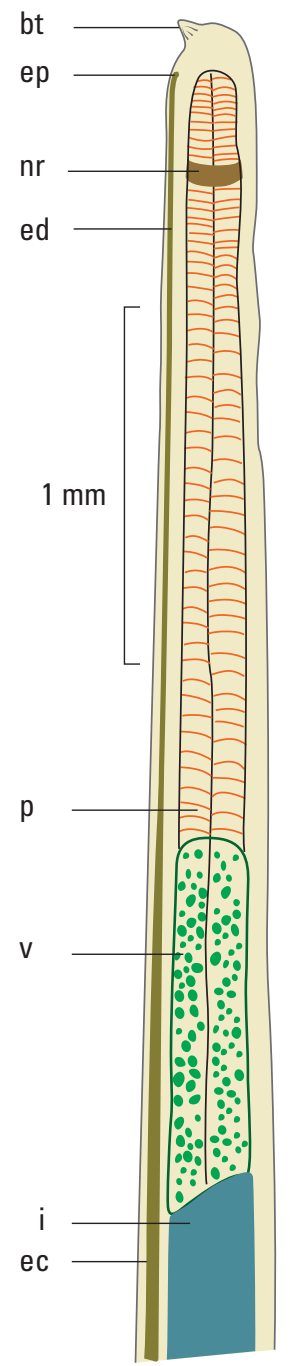

B. Head-Contracaecum/Phocascaris

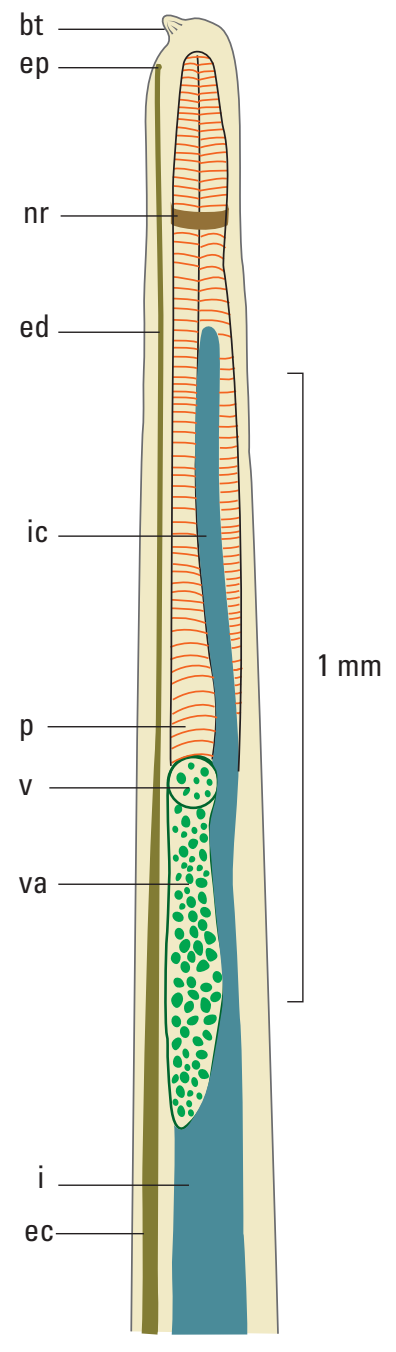

C. Head-Pseudoterranova

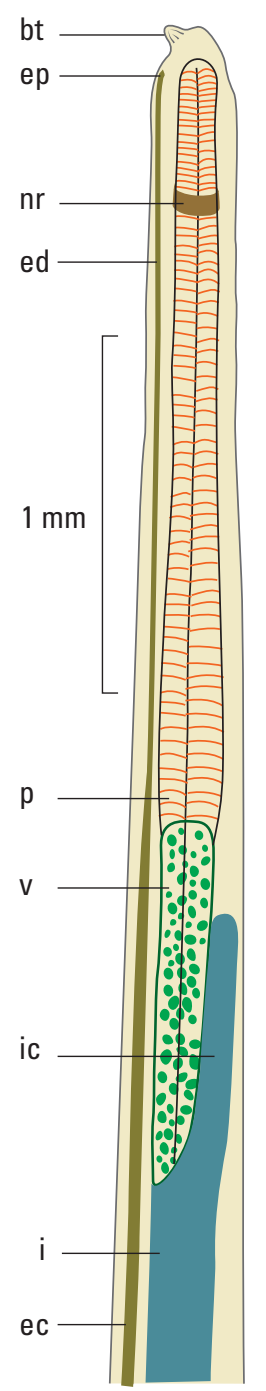

Figure 4. Key morphological features of anisakid larvae removed from fish: $A$, Anisakis; $B$, Contracaecum/Phocascaris; C, Pseudoterranova. Note proventriculus (p), ventriculus (v), intestine (i), intestinal caecum (ic), ventricular appendage (va), boring tooth (bt), excretory pore (ep), nerve ring (nr), excretory duct (ed), excretory canal (ec). 


\section{Disease Ecology}

The life cycle of Anisakis spp. is complex and involves pelagic invertebrates such as small shrimplike crustaceans or euphausiids (commonly called krill) or squid and pelagic fish such as capelin, herring, salmon, or redfish as intermediate or transport hosts, with cetaceans as definitive hosts. The life cycle of Pseudoterranova spp. is similar but involves benthic invertebrates such as amphipods (commonly called scud), and benthic fish such as flatfish and cod as intermediate hosts, with pinnipeds as definitive hosts.

Anisakis spp. reproduce in the stomach of cetaceans such as minke whales and beluga and harbor porpoises (fig. 5).
Female worms produce eggs, which enter the sea with the feces of the cetacean. A period of development is required in the sea before larval stages hatch from eggs. These larvae are then eaten by a necessary, or "obligate," first intermediate host such as krill, where larvae develop and grow considerably, reaching 7-39 millimeters $(\mathrm{mm})$ in length. Infected krill are subsequently eaten by a transport host such as squid or small pelagic fish (capelin, mackerel, herring). These infected fish or squid are in turn eaten by large pelagic predatory fish such as redfish, salmon, or silver hake, which can accumulate large numbers of infective larvae. Finally, the life cycle is completed when the definitive cetacean host eats fish (small or large fish) or krill containing infective larvae. Larval stages

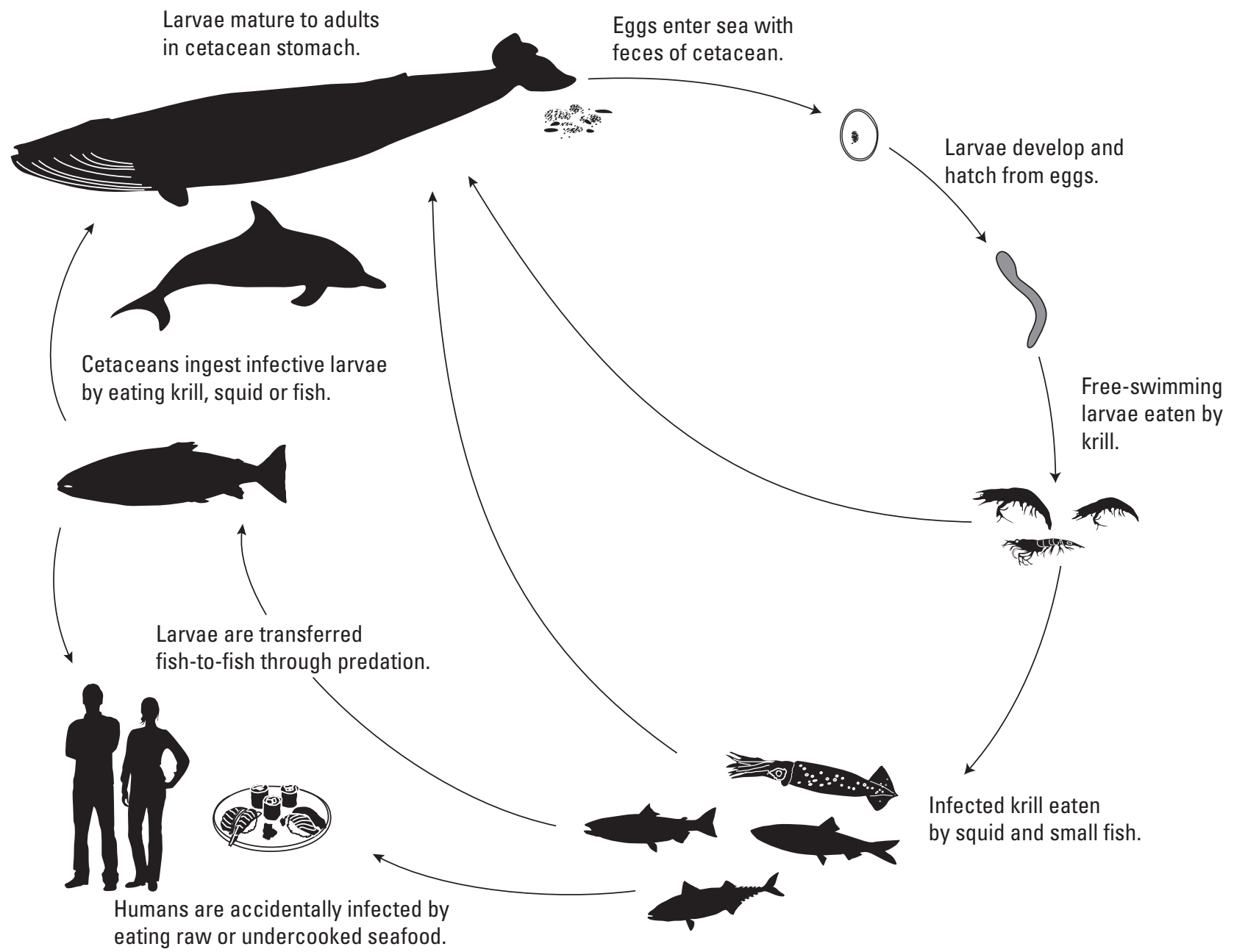

Figure 5. The life cycle of Anisakis simplex. (Adapted from Anderson, 2000) 
in fish are small (9-39 $\mathrm{mm}$ long) and are usually found in a flat coil on the visceral organs (fig. 6). They may also occur in the flesh of fish where they are difficult to see, because they are transparent or white in color. Larvae may migrate from the visceral organs into the muscle after death, especially if the fish is allowed to warm to room temperature.

Pseudoterranova spp. reproduces in the stomach of pinnipeds such as grey seals (fig. 7). Female worms produce eggs that enter the sea with the feces of the seal. A period of development is required in the sea before larval stages hatch from eggs. These larvae attach to sand or rocks by their tails and are eaten by a first host such as copepods or immature or mature invertebrates such as mysids, amphipods, isopods, and polychaetes. Infected invertebrates are subsequently eaten by a second host such as small benthic fish (sculpins, smelt, juvenile cod, and flatfish). These small infected fish are in turn eaten by large benthic predatory fish such as large cod, monkfish, and eelpout, which can accumulate large numbers of infective larvae. Finally the life cycle is completed when the definitive seal host eats small or large fish containing infective larvae. The biology of Pseudoterranova spp. is not completely understood, particularly the role of invertebrates and small fish (McClelland, 2002; Smith and Hemmingsen, 2003). Larval stages in fish grow considerably, from more than 2- $60 \mathrm{~mm}$ long, depending on the size of fish and its age when it is infected. Larvae may also reside in the gut wall, liver, or body cavity of fish, but most are found in the muscles (fig. 8). As larvae are yellow to red in color and relatively large, they are often seen in the fillets, much to the alarm of consumers. Larvae may or may not be encapsulated and may lie coiled or fully extended in tissues, but this may be a function of host species, temperature, or age of infection (Ramakrishna and Burt, 1991; McClelland, 1995). Pseudoterranova spp. larvae may also migrate after the death of the fish. Similarly, another related anisakid, Hysterothylacium aduncum, which matures in the intestine of fish such as cod, can migrate after the host dies by exiting from its anus, mouth, or gills and is often misidentified as Pseudoterranova spp.

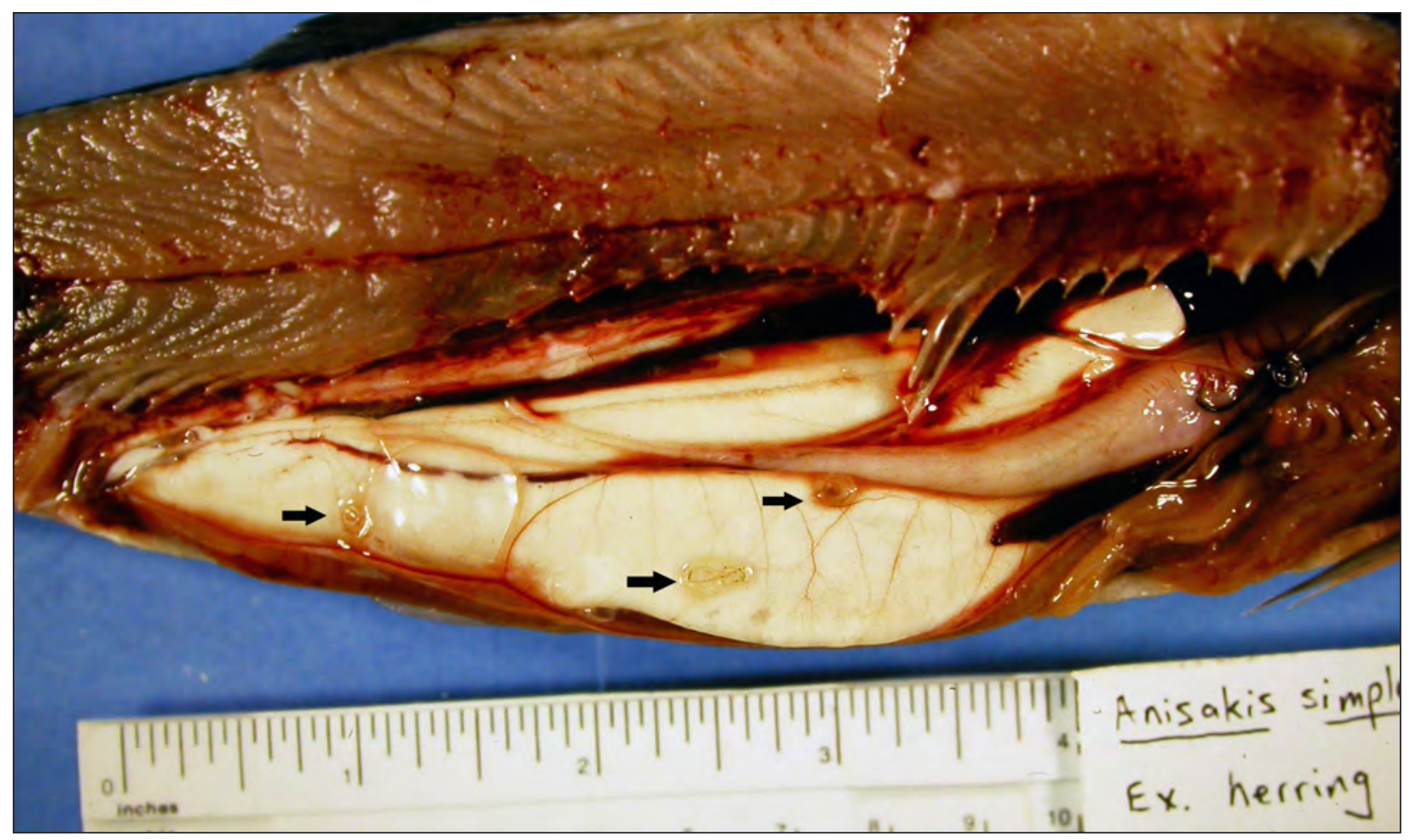

Figure 6. Larval Anisakis sp. (arrows) in the abdominal cavity of an Atlantic herring. (Photo by Dr. Lena Measures, Fisheries and Oceans Canada) 


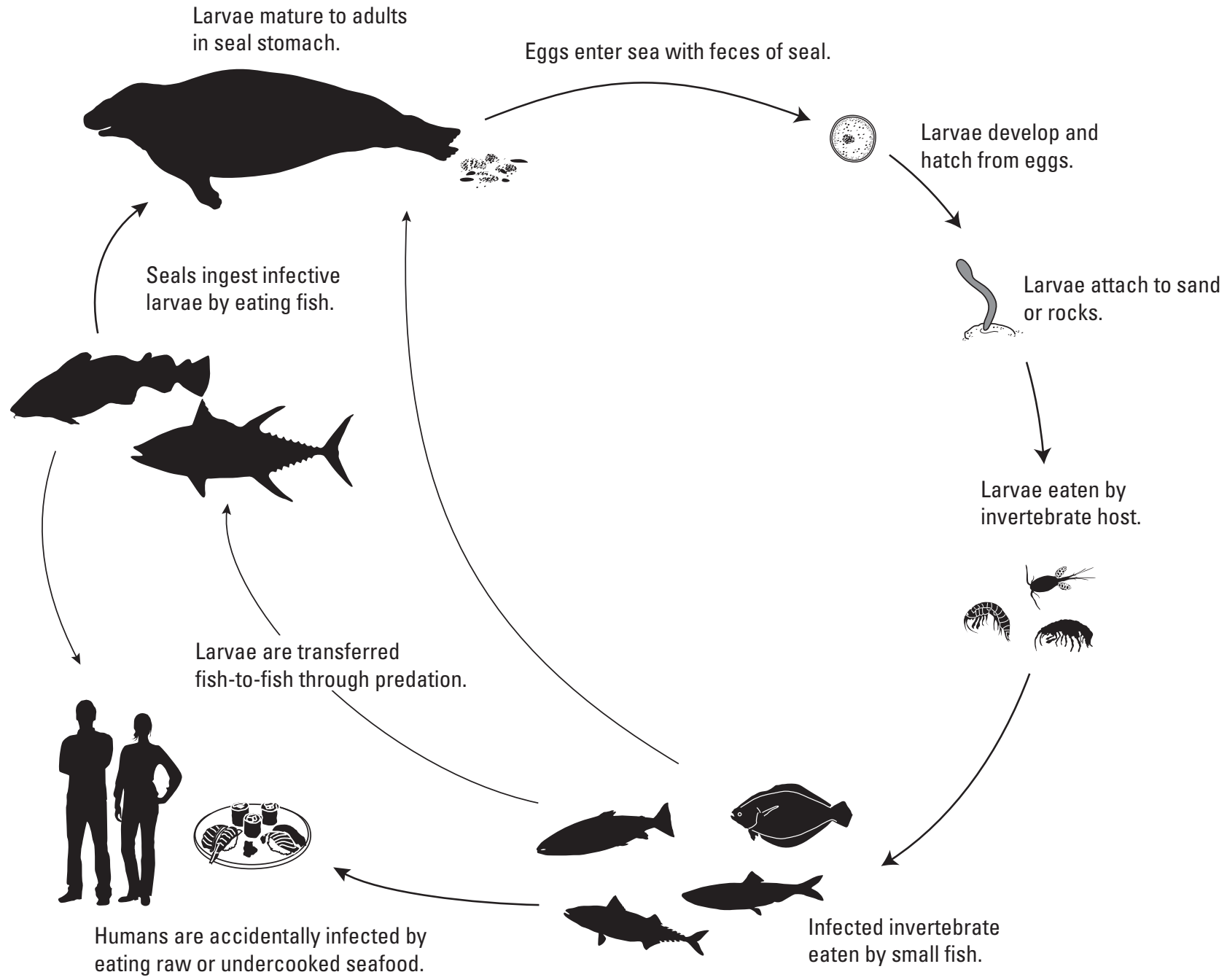

Figure 7. The life cycle of Pseudoterranova decipiens. (Adapted from McClelland, 2002, and Anderson, 2000)

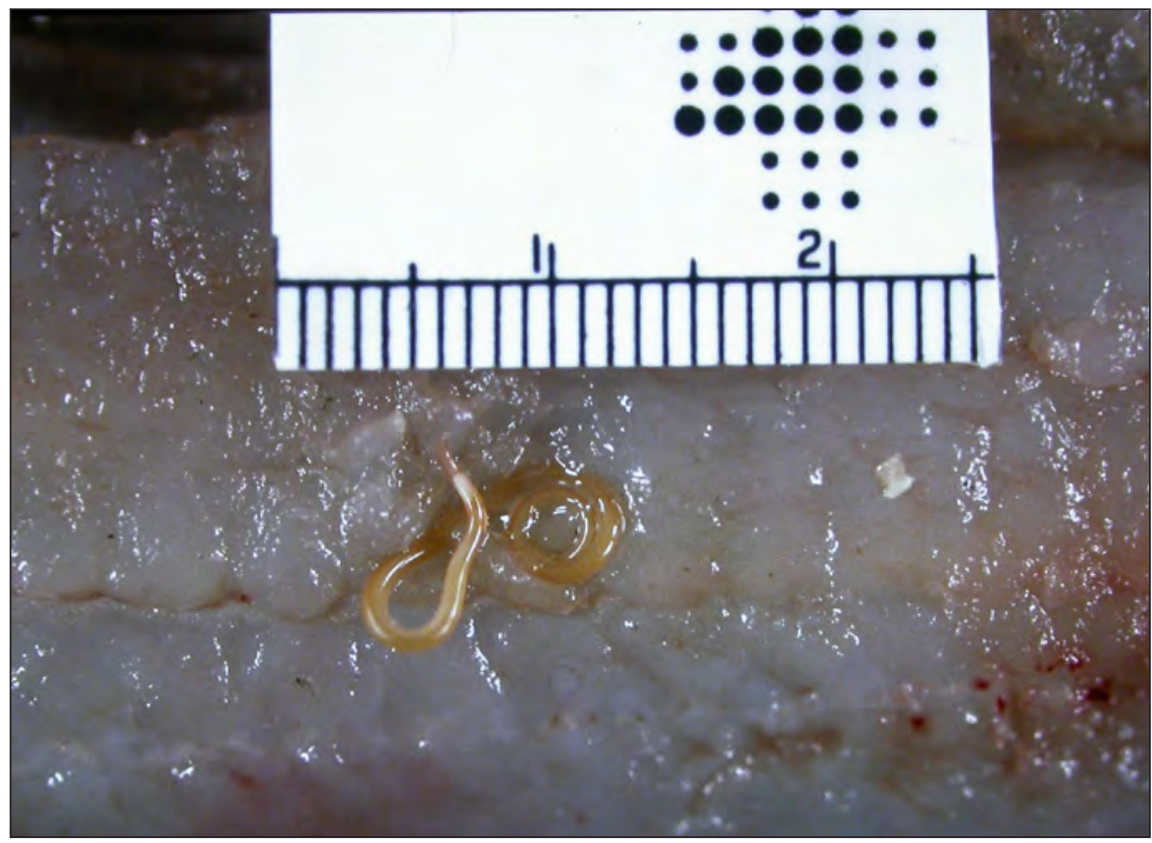

Figure 8. Larval Pseudoterranova sp. in muscle of an American plaice. (Photo by Dr. Lena Measures, Fisheries and Oceans Canada) 


\section{Migration of Adult Hysterothylacium aduncum in Atlantic Cod After Host Death}

Post-mortem migration of nematodes is a well recognized phenomenon observed by parasitologists, fishermen, hunters, wildlife biologists, and others. It is particularly common in coldblooded animals such as fish when the temperature of a recently caught fish increases above that of its original habitat in water. The rise in temperature stimulates some parasites in fish tissues to migrate within the body of the fish or even to exit the body completely. In the figure below, Hysterothylacium aduncum, a parasitic nematode found as adults in the digestive tract of Atlan- tic cod, the definitive host, leave the fish via the vent, mouth, or gills. Many marine fishermen are familiar with sealworm, Pseudoterranova decipiens, which uses cod as an intermediate host in which larval stages occur in the muscles. Although sealworm larvae migrate within the tissues of cod, even when cod are still alive, many fishermen mistake $H$. aduncum for sealworm when they observe a fish as illustrated in the figure below. Post-mortem migration by $\mathrm{H}$. aduncum can be eliminated by gutting fresh cod immediately after capture.

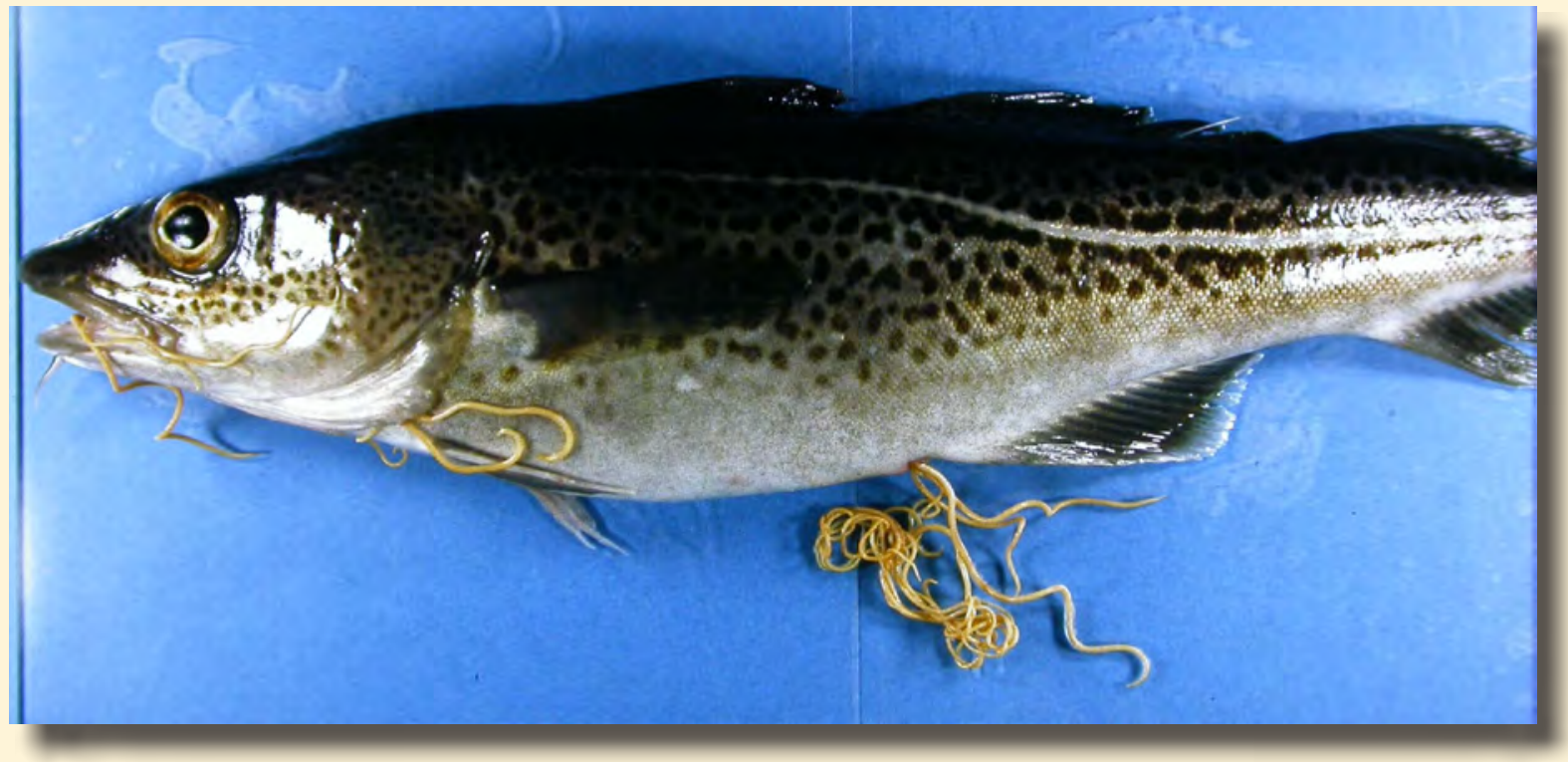

Hysterothylacium aduncum, a parasitic nematode of Atlantic cod, may be mistaken for $\boldsymbol{P}$. decipiens as they exit the body of a dead fish through the vent, mouth, or gills. (Photo by Dr. Lena Measures, Fisheries and Oceans Canada) 


\section{Commercial Candling of Fish Fillets to Visualize and Extract Pseudoterranova decipiens}

Candling of fish in fish-processing plants is commonly carried out in areas of the world where fish are frequently infected with parasitic nematodes such as sealworm, Pseudoterranova decipiens, because worms look unsavory to fish consumers. Candling allows the workers to see the worms and remove them from fish fillets. Fillets are sliced to a predetermined thickness and placed on a light table. Light passing through the fillet from below enables workers to see large, yellow to red larval sealworms and then remove them using forceps. As the efficacy of detection and removal depends on various factors such as the thickness of the fish fillet, the number of worms present, their size, the intensity of light used, and observer experience, candling is not 100 percent efficient. Candling involves considerable cost to fish processers and diminishes the quality and value of fillets.

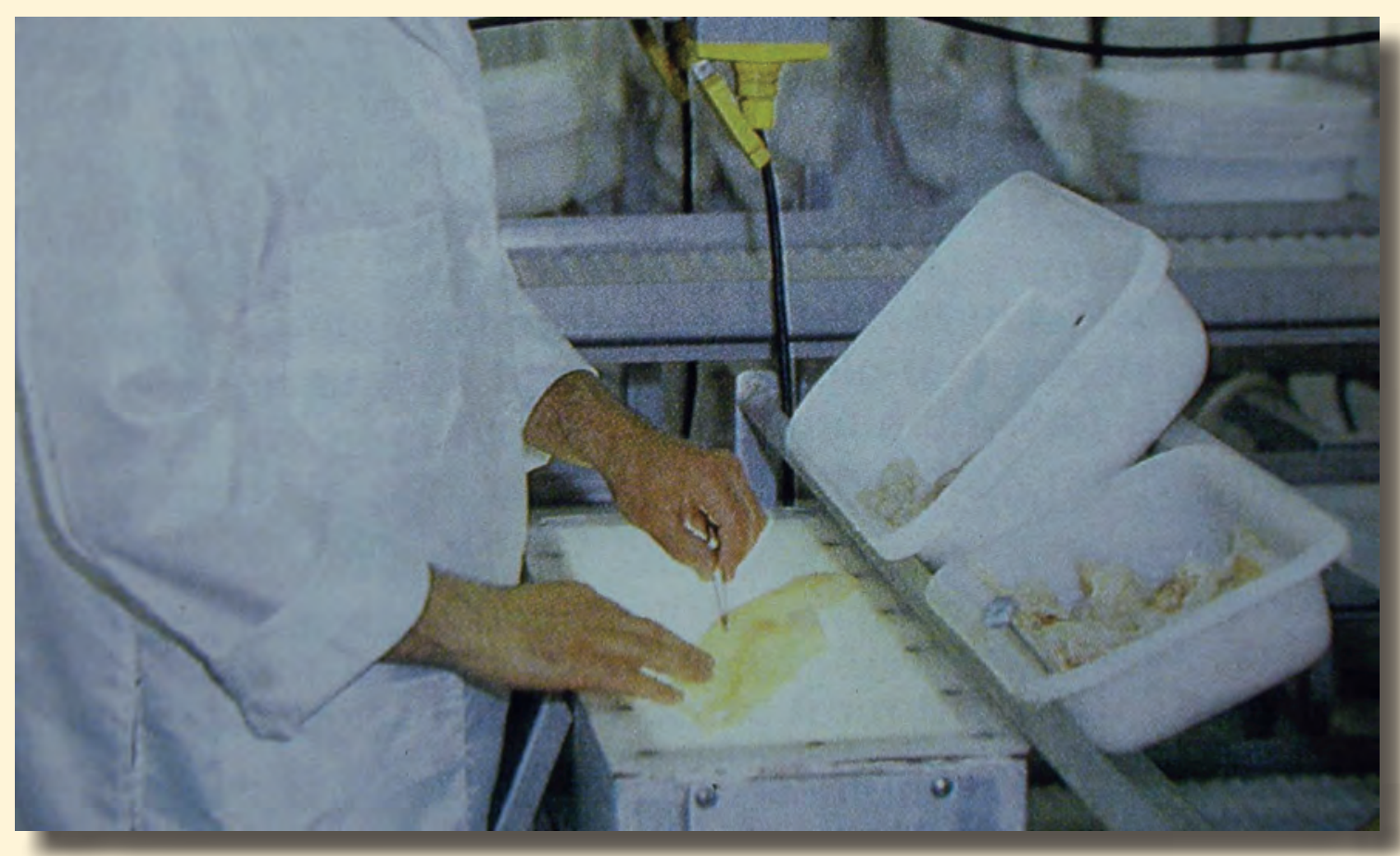

Candling of fish fillets to visualize and remove larval worms. (Photo by Dr. Lena Measures, Fisheries and Oceans Canada) 


\section{Points to Ponder}

Most professional chefs in "sushi-bars" or high quality restaurants that serve sashimi, ikasashi, or ceviche are trained in the proper handling of raw fish or squid for safe consumption by their customers. It is more commonly the home chef preparing his own fish dish that has an intimate experience with parasitic worms (Kates and others, 1973; Oshima, 1987; Kagei and Isogaki, 1992; Maejima and others, 1992; Couture and others, 2003). The risk of anisakid infection from consuming farmed fish (those raised in sea pens, cages, or sea nets in aquacultural operations where fish are fed a commercial food, usually dry or expanded pellets) is considered low (Deardorff and Kent, 1989; Inoue and others, 2000).

\section{Disease Prevention and Control}

Infective larval Anisakis spp. and Pseudoterranova spp. are remarkably resistant to various environmental conditions. In fish flesh they can survive cold smoking, insufficient marination or salting, and freezing temperatures (Hauck, 1977; Bier, 1976; Deardorff and Throm, 1988; Gardiner, 1990; Wharton and Aalders, 2002). Several methods of fish preparation can be used to reduce the chance of acquiring infections (table 6). Rapid evisceration of freshly caught fish is important should there be larvae in the viscera or body cavity (Smith and Wootten, 1975). Larval Anisakis spp. in fish flesh is problematic for consumers, because its small size and transparent or white color makes it difficult to detect. On the other hand, larval Pseudoterranova spp., which is commonly commonly found in fish flesh, is often seen by the consumer, depending on the thickness of fish fillets. Slicing fish fillets and using a strong light source to visualize larvae and then remove them manually (a process called candling) is still used commercially in some fish processing plants, but candling is costly, diminishes the value of the product, and is inefficient as its efficacy depends on the thickness of the fillet being examined (Power,
1958, 1961; Valdimarsson and others, 1985; Hafsteinsson and Rizvi, 1987). An effective research tool to detect and obtain live larval anisakids from infected invertebrates, fish, or other tissue is artificial digestion using a Baermann apparatus.

Research has shown that commercial blast-freezing of infected fish to at least -35 degrees Celsius $\left({ }^{\circ} \mathrm{C}\right)$ for 15 hours will kill larvae (Deardorff and Throm, 1988). However, larval survival in fish flesh is dependent on the mass of the fish being frozen. For example, 20-kilogram (kg) boxes of monkfish required more than 28 hours to reach the commercial blast freezer temperature of $-35^{\circ} \mathrm{C}$ to $-38^{\circ} \mathrm{C}$ (Wharton and Aalders, 2002). Furthermore, it is important that all parts of the fish freeze solid at these temperatures and for the required time to ensure killing any larvae that may be present. According to the U.S. Food and Drug Administration, raw, rawmarinated, partially cooked, or marinated partially cooked fish must be frozen at $-35^{\circ} \mathrm{C}$ or below until solid and stored at this temperature or below for 15 hours to destroy larvae. Similarly, freezing these products at $-20{ }^{\circ} \mathrm{C}$ or below for a minimum of 168 hours (7 days) will also destroy larvae (U.S. Food and Drug Administration, 2009). Cooking fish thoroughly so that the internal temperature of the fish attains $60-63{ }^{\circ} \mathrm{C}$ for a few minutes will kill larvae (Oshima, 1972; U.S. Food and Drug Administration, 2009).

Table 6. Methods to reduce risk of infection by anisakid larvae for consumers of fish.

$\left[{ }^{\circ} \mathrm{C}\right.$, degrees Celsius $]$

- Rapid evisceration of fish to prevent postmortem migration of larvae into muscles.

- Candling and manual removal of larvae.

- Solid freezing of fish. The time required to freeze fish solid depends on the mass of the fish. Recommended to freeze fish at $-20{ }^{\circ} \mathrm{C}$ for a minimum of 7 days.

- Thorough cooking of fish to an internal temperature of $60-63{ }^{\circ} \mathrm{C}$ for several minutes. 


\section{The Baermann Technique}

The Baermann technique is a method commonly employed in laboratories to concentrate and collect live organisms from a large sample of soil, water, or tissue. It was developed by G. Baermann in 1917 to recover hookworm larvae from soil samples (Baermann, 1917). It consists of a funnel with a plastic tube at the bottom that is closed with a stopcock, which can be opened to remove small samples or liquids containing organisms that have accumulated in the plastic tube. A sample of soil or tissue may be placed on a sieve or filter suspended in the top part of the funnel. A liquid medium such as water may or may not be used. There are various modifications of the Baermann apparatus. A light may be suspended above the funnel to encourage light-averse organisms to migrate downward, a technique frequently used by entomologists to collect some insects or soil organisms. In parasitology, a modified version may involve preparing a pepsin solution to simulate the digestive juices in the stomach of a mammal or bird. This solution is poured into the funnel with the stopcock closed, and infected tissue such as that from a fish or invertebrate is placed on a sieve or filter within the fluid at the top of the funnel. The apparatus may be kept at room temperature, 37 degrees Celsius $\left({ }^{\circ} \mathrm{C}\right)$ or $42{ }^{\circ} \mathrm{C}$ depending on the sample. Enzymes in the pepsin solution slowly digest the tissue, such as fish muscle containing larval Anisakis simplex, and the enzymes and warm solution stimulate the larvae to migrate out of the tissues and fall downward into the plastic tube where, after a few hours incubation, they may be collected. Samples of krill can also be digested in this manner to collect larval Anisakis spp. (Hays and others, 1998).

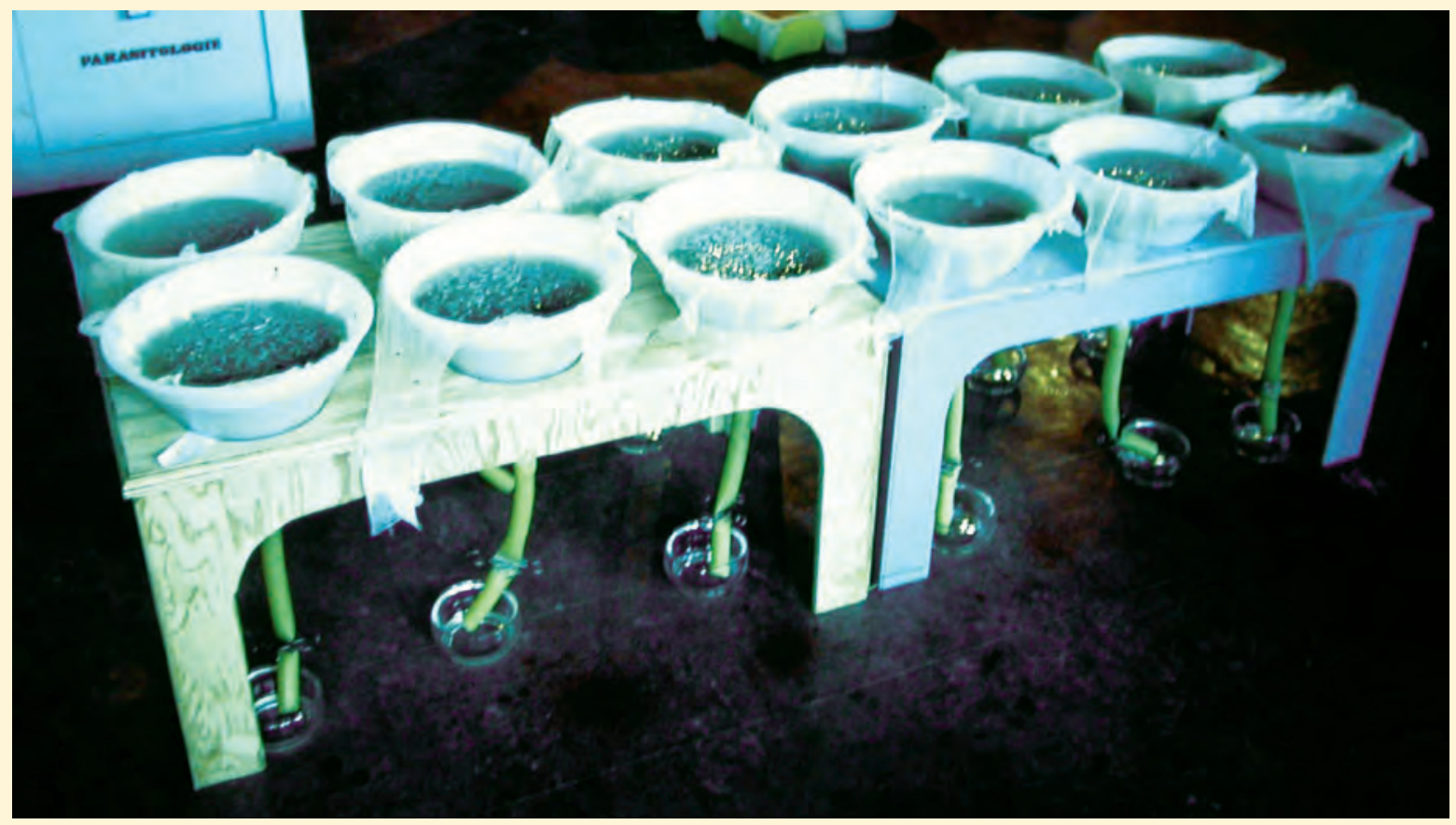

Baermann apparatus. (Photo by Dr. Lena Measures, Fisheries and Oceans Canada) 


\section{References Cited}

Abollo, E., Gestal, C., López, A., González, A.F., Guerra, A., and Pascal, S., 1998, Squid as trophic bridges for parasite flow within marine ecosystems: the case of Anisakis simplex (Nematoda: Anisakidae), or when the wrong way can be right: South African Journal of Marine Sciences, v. 20, p. 223-232.

Abollo, E., Paggi, L., Pascual, S., and D 'Amelio, S., 2003, Occurrence of recombinant genotypes of Anisakis simplex s.s. and Anisakis pegreffii (Nematoda: Anisakidae) in an area of sympatry: Infection, Genetics and Evolution, v. 3, p. $175-181$.

Alonso-Gómez, A., Moreno-Ancillo, A., Concepción LópezSerrano, M., Suarez-de-Parga, J.M., Daschner, A., Caballero, M.T., Barranco, P., and Cabañas, R., 2004, Anisakis simplex only provokes allergic symptoms when the worm parasitizes the gastrointestinal tract: Parasitology Research, v. 93 , p. 378-384.

Amin, O.M., Eidelman, W.S., Domke, W., Bailey, J., and Pfeifer, G., 2000, An unusual case of anisakiasis in California, U.S.A.: Comparative Parasitology, v. 67, p. 71-75.

Anderson, R.C., 2000, The superfamily Ascaridoidea, in Anderson, R.C., ed., Nematode parasites of vertebrates: their development and transmision: Oxon, United Kingdom, CABI Publishing, p. 267-314.

Asami, K., Watanuki, T., Sakai, H., Imano, H., and Okamoto, R., 1965, Two cases of stomach granuloma caused by Anisakis-like larval nematodes in Japan: American Journal of Tropical Medicine and Hygiene, v. 14, p. 119-123.

Aspholm, P.E., Ugland, K.I., Jødestøl, K.A., and. Berland, B., 1995, Sealworm (Pseudoterranova decipiens) infection in common seals (Phoca vitulina) and potential intermediate fish hosts from the Outer Oslofjord: International Journal for Parasitology, v. 25, p. 367-373.

Audicana, M.T., Ansotegui, I.J., Fernández de Corres, L., and Kennedy, M.W., 2002, Anisakis simplex: dangerous-dead and alive?: Trends in Parasitology, v. 18, p. 20-25.

Babin, P., Raga, J.A., and Duguy, R., 1994, Ulcères parasitaires gastriques chez les cétacés odontocètes échoués sur les côtes de France: Point Vétérinaire, v. 26, p. 77-81.

Baermann, G., 1917, Uber Ankylostomiasis, deren Ausbreitungs-bedingungen durch die Bodeninfection, und deren Bekämpfung: Geneesk. Tijdschr. Nederl. Indie, Batavia, v. 57, p. 579-669.
Baker, J.R., and Martin, A.R., 1992, Causes of mortality and parasites and incidental lesions in harbor porpoises (Phocoena phocoena) from British waters: Veterinary Record, v. 130, p. $554-558$.

Beck, M., Evans, R., Feist, S.W., Stebbing, P., Longshaw, M., and Harris, E., 2008, Anisakis simplex sensu lato associated with red vent syndrome in wild adult Atlantic salmon Salmo salar in England and Wales: Diseases of Aquatic Organisms, v. 82, p. 61-65.

Berón-Vera, B., Crespo, E.A., Raga, J.A., and Fernández, M., 2007, Parasite communities of common dolphins (Delphinus delphis) from Patagonia: the relation with host distribution and diet and comparison with sympatric hosts: Journal of Parasitology, v. 93, p. 1056-1060.

Berón-Vera, B., Crespo, E.A., and Raga, J.A., 2008, Parasites in stranded cetaceans of Patagonia: Journal of Parasitology, v. 94, p. 946-948.

Bhat, M., and Cleland, P., 2010, Gastric anisakiasis: Clinical Gastroenterology and Hepatology, v. 8, p. A20.

Bier, J.W., 1976, Experimental anisakiasis: cultivation and temperature tolerance determinations: Journal of Milk and Food Technology, v. 39, p. 132-137.

Brattey, J., and Stenson, G.B., 1993, Host specificity and abundance of parasitic nematodes (Ascaridoidea) from the stomachs of five phocid species from Newfoundland and Labrador: Canadian Journal of Zoology, v. 71, p. 2156-2166.

Brattey, J., and Stenson, G.B., 1995, Helminth parasites of the alimentary tract of the harbor porpoise, Phocoena phocoena (L.), from Newfoundland and Labrador: Journal of the Helminthological Society of Washington, v. 62, p.209-216.

Brattey, J., and Davidson, W.S., 1996, Genetic variation within Pseudoterranova decipiens (Nematoda: Ascaridoidea) from Canadian Atlantic marine fishes and seals: characterization by RFLP analysis of genomic DNA: Canadian Journal of Fisheries and Aquatic Sciences, v. 53, p. 333-341.

Chitwood, M.B., 1975, Phocanema-type larval nematode coughed up by a boy in California: American Journal of Tropical Medicine and Hygiene, v. 24, p. 710-711.

Clavel, A., Delgado, B., Sanchez-Acedo, C., Carbonell, E., Castillo, J., Ramirez, J., Quilez, J., Gomez-Lus, R., and Kagei, N., 1993, A live Anisakis physeteris larva found in the abdominal cavity of a woman in Zaragoza, Spain: Japanese Journal of Parasitology, v. 42, p. 445-448. 
Colón-Llavina, M.M., Mignucci-Giannoni, A.A., Mattiucci, S., Paoletti, M., Nascetti, G., and Williams Jr., E.H., 2009, Additional records of metazoan parasites from Caribbean marine mammals, including genetically identified anisakid nematodes: Parasitology Research, v. 105, p. 1239-1252.

Couture, C., Measures, L., Gagnon, J., and Desbiens, C., 2003, Human intestinal anisakiosis due to consumption of raw salmon: American Journal of Surgical Pathology, v. 27, p. $1167-1172$.

D’Amelio, S., Mathiopoulos, K.D., Santos, C.P., Pugachev, O.N., Webb, S.C., Picanço, M., and Paggi, L., 2000, Genetic markers in ribosomal DNA for the identification of members of the genus Anisakis (Nematoda: Ascaridoidea) defined by polymerase chain reaction-based restriction fragment length polymorphism: International Journal for Parasitology, v. 30, p. 223-226.

Davey, J.T., 1971, A revision of the genus Anisakis Dujardin, 1845 (Nematoda: Ascaridata): Journal of Helminthology, v. XLV, p. 51-72

Deardorff, T.L., and Kent, M.L., 1989, Prevalence of larval Anisakis simplex in pen-reared and wild-caught salmon (Salmonidae) from Puget Sound, Washington: Journal of Wildlife Diseases, v. 25, p. 416-419.

Deardorff, T.L., and Overstreet, R.M., 1981, Terranova ceticola $\mathrm{n}$. sp. (Nematoda: Anisakidae) from the dwarf sperm whale, Kogia simus (Owen), in the Gulf of Mexico: Systematic Parasitology, v. 3, p. 25-28.

Deardorff, T.L., and Thom, R., 1988, Commercial blast-freezing of third-stage Anisakis simplex larvae encapsulated in salmon and rockfish: Journal of Parasitology, v. 74, p. 600-603.

De Guise, S., Lagacé, A., and Béland, P., 1994, Gastric papillomas in eight St. Lawrence beluga whales (Delphinapterus leucas): Journal of Veterinary Diagnostic Investigations, v. 6 , p. $385-388$.

De Guise, S., Lagacé, A., Béland, P., Girard, C., and Higgins, R., 1995, Non-neoplastic lesions in beluga whales (Delphinapterus leucas) and other marine mammals from the St. Lawrence Estuary: Journal of Comparative Pathology, v. 112 , p. $257-271$.

Desowitz, R.S., 1986, Human and experimental anisakiasis in the United States: Hokkaido Medical Journal, v. 61, p. $358-371$.

Eskesen, A., Strand, E.A., Andersen, S.N., Rosseland, A., Hellum, K.B., and Strand, Ø.A., 2001, Anisakiasis presenting as an obstructive duodenal tumor-A Scandinavian case: Scandinavian Journal of Infectious Diseases, v. 33, p. 75-76.
Food Safety Network, 2009, Safe preparation and storage of aboriginal traditional/country foods: A review: accessed June 11, 2014 at $h t t p: / / w w w . n c c e h . c a / e n / p r a c t i c e \_p o l i c y /$ ncceh_reviews/aboriginal_foods.

Gardiner, M.A., 1990, Survival of Anisakis in cold smoked salmon: Canadian Institute of Food Science and Technology Journal, v. 23, p. 143-144.

Hafsteinsson, H., and Rizvi, S.H., 1987, A review of the sealworm problem: biology, implications and solutions: Journal of Food Production, v. 50, p. 70-84.

Harper, C.G., Feng, Y., Xu, S., Taylor, N.S., Kinsel, M., Dewhirst, F.E., Paster, B.J., Greenwell, M., Levine, G., Rogers, A., and Fox, J.G., 2002a, Helicobacter cetorum sp. nov., a urease-positive Helicobacter species isolated from dolphins and whales: Journal of Clinical Microbiology, v. 40, p. $4536-4543$.

Harper, C.M.G., Xu, S., Feng, Y., Dunn, J.L., Taylor, N.S., Dewhirst, F.E., and Fox, J.G., 2002b, Identification of novel Helicobacter spp. from a beluga whale: Applied and Environmental Microbiology, v. 68, p. 2040-2043.

Hauck, A.K., 1977, Occurrence and survival of the larval nematode Anisakis sp. in the flesh of fresh, frozen, brined, and smoked Pacific herring, Clupea harengus Pallasi: Journal of Parasitology, v. 63, p. 515-519.

Hays, R., Measures, L.N., and Huot, J., 1998, Euphausiids as intermediate hosts of Anisakis simplex in the St. Lawrence estuary: Canadian Journal of Zoology, v. 76, p. 1226-1235.

Hitchcock, D.J., 1950, Parasitological study on the Eskimos in the Bethel area of Alaska: Journal of Parasitology, v. 36, p. 232-234.

Iñiguez, A.M., Santos, C. P., and Vincente, A.C.P., 2009, Genetic characterization of Anisakis typica and Anisakis physeteris from marine mammals and fish from the Atlantic Ocean off Brazil: Veterinary Parasitology, v. 165, p. $350-356$.

Inoue, K., Oshima, S.-I., Hirata, T., and Kimura, I., 2000, Possibility of anisakid larvae infection in farmed salmon: Fisheries Science, v. 66, p. 1049-1052.

Ishikura, H., Kikuchi, K., Nagasawa, K., Ooiwa, T., Takamiya, H., Sato, N., and Sugane, K., 1992, Anisakidae and anisakidosis, in Sun, T., ed., Progress in clinical parasitology, v. 3: New York, Springer-Verlag, p. 43-102.

Jackson, G.J., 1975, The "new disease" status of human anisakiasis and North American cases: a review: Journal of Milk and Food Technology, v. 38, p. 769-773. 
Jenkins, E.J., Castrodale, L.J., de Rosemond, J.C., Dixon, B.R., Elmore, S.A., Gesy, K.M., Hoberg, E.P., Polley, L., Schurer, J.M., Simard, M., and Thompson, R.C.A., 2013, Tradition and transition: Parasitic zoonoses of people and animals in Alaska, Northern Canada, and Greenland: Advances in Parasitology, v. 82, p. 33-204.

Johansson, E., Aponno, M., Lundberg, M., and van HageHamsten, M., 2001, Allergenic cross-reactivity between the nematode Anisakis simplex and the dust mites Acarus siro, Lepidoglyphus destructor, Tyrophagus putrescentiae, and Dermatophagoides pteronyssinus: Allergy, v. 56, p. 660-666.

Johnston, T. H., and Mawson, P.M., 1939, Internal parasites of the pigmy sperm whale: Records of the South Australian Museum, v. 6, p. 263-274.

Kagei, N., and Isogaki, H., 1992, A case of abdominal syndrome caused by the presence of a large number of Anisakis larvae: International Journal for Parasitology, v. 22, p. 251-253.

Kagei, N., Orikasa, H., Hori, E., Sannomiya, A., and Yasumura, Y., 1995, A case of hepatic anisakiasis with a literal survey for extra-gastrointestinal anisakiasis: Japanese Journal of Parasitology,v. 44, p. 346-351.

Kassai, T., Cordero Del Campillo, M., Euzeby, J., Gaafar, S., Hiepe, T., and Himonas, C.A., 1988, Standardized nomenclature of animal parasitic diseases (SNOAPAD): Veterinary Parasitology, v. 29, p. 299-326.

Kates, S., Wright, K.A., and Wright, R., 1973, A case of human infection with the cod nematode Phocanema sp.: American Journal of Tropical Medicine and Hygiene, v. 22, p. 606-608.

Kliks, M., 1983, Anisakiasis in the western United States: four new case reports from California: American Journal of Tropical Medicine and Hygiene, v. 32. p. 526-532.

Klimpel, S., Busch, M.W., Kuhn, T., Rohde, A., and Palm, H.W., 2010, The Anisakis simplex complex off the South Shetland Islands (Antarctica): endemic populations versus introduction through migratory hosts: Marine Ecology Progress Series, v. 403, p. 1-11.

Klimpel, S., Kellermanns, E., and Palm, H.W., 2008, The role of pelagic swarm fish (Myctophidae: Teleostei) in the oceanic life cycle of Anisakis sibling species at the MidAtlantic Ridge, Central Atlantic: Parasitology Research, v. 104 , p. 43-53.

Klimpel, S., Palm, H.W., Rückert, S., and Piatkowski, U., 2004, The life cycle of Anisakis simplex in the Norwegian Deep (northern North Sea): Parasitology Research, v. 94, p. $1-9$.
Kuipers, F.C., Van Thiel, P.H., and Roskam, R. T., 1960, Eosinofiele flegmone van de dunne darm, veroorzaakt door een niet aan het lichaam van de mens aangepaste worm: Nederlands Tijdschrift voor Geneeskunde, v. 104, p. 422-427.

Kuramochi, T., Machida, M., Araki, J., Uchida, A., Kishiro, T., and Nagasawa, K., 1996, Minke whales (Balaenoptera acutorostrata) are one of the major final hosts of Anisakis simplex (Nematoda: Anisakidae) in the Northwestern North Pacific Ocean: Report of the International Whaling Commission, v. 46, p. 415-419.

Lair, S., Martineau, D., and Measures, L., 2014, Causes of mortality in St. Lawrence Estuary beluga (Delphinapterus leucas) from 1983 to 2012: DFO Canadian Science Advisory Secretariat Research Document 2013/119, Iv, 37 p.

Larrat, S., Bouchard, F., Séguin, G., and Lair, S., 2013, Relationship between red vent symdrome and anisakid larvae burden in wild Atlantic salmon (Salmo salar): Journal of Wildlife Diseases, v. 49, p. 229-234.

Lichtenfels, J.R., and Brancato, F.P., 1987, Anisakid larva from the throat of an Alaskan Eskimo: American Journal of Tropical Medicine and Hygiene, v. 25, p. 691-693.

Little, M.D., and McPhail, J.C., 1972, Large nematode larva from the abdominal cavity of a man in Massachusetts: American Journal of Tropical Medicine and Hygiene, v. 21, p. 948-950.

Little, M.D., and Most, H., 1973, Anisakid larva from the throat of a woman in New York: American Journal of Tropical Medicine and Hygiene, v. 22, p. 609-612.

Lorenzo, S., Iglesias, R., Leiro, J., Ubeira, F.M., Ansotegui, I., Garcia, M., and Fernández de Corres, L., 2000, Usefulness of currently available methods for the diagnosis of Anisakis simplex allergy: Allergy, v. 55, p. 627-633.

Maejima, J., Fukumoto, S., Yazaki, S., Hirai, K., Hasegawa, H., and Takagi, H., 1992, Morphological features of an adult of Pseudoterranova decipiens (Krabbe, 1878) found in human stomach wall: Japanese Journal of Parasitology, v. 41, p. $420-424$.

Margolis, L., 1977, Public health aspects of "codworm" infection: a review: Journal of the Fisheries Research Board of Canada, v. 34, p. 887-898.

Martineau, D., Lagacé, A., Béland, P., Higgins, R., Armstrong, D., and Shugart, L.R., 1988, Pathology of stranded beluga whales (Delphinapterus leucas) from the St. Lawrence Estuary, Québec, Canada: Journal of Comparative Pathology, v. 98, p. 287-311. 
Martín-Sánchez, J., Artacho-Reinoso, M.E., Díaz- Gavilán, M., Valero-López, A., 2005, Structure of Anisakis simplex s.l. populations in a region sympatric for $A$. pegreffi and $A$. simplex s.s. Absence of reproductive isolation between both species: Molecular and Biochemical Parasitology, v. 141, p. $155-162$.

Mattiucci, S., Abaunza, P., Ramadori, L., and Nascetti, G., 2004, Genetic identification of Anisakis larvae in European hake from Atlantic and Mediterranean waters for stock recognition: Journal of Fish Biology, v. 65, p. 495-510.

Mattiucci, S., and Nascetti, G., 2008, Advances and trends in the molecular systematics of anisakid nematodes, with implications for their evolutionary ecology and host-parasite co-evolutionary processes: Advances in Parasitology, v. 66, p. $47-148$.

Mattiucci, S., Paoletti, M., and Webb, S.C., 2009, Anisakis nascettii $\mathrm{n}$. sp. (Nematoda: Anisakidae) from beaked whales of the southern hemisphere: morphological description, genetic relationships between congeners and ecological data: Systematic Parasitology, v. 74, p. 199-217.

Mattiucci, S., Cipriani, P., Webb, S.C., Paoletti, M., Marcer, F., Bellisario, B., Gibson, D.I., and Nascetti, G., 2014, Genetic and morphological approaches distinquish the three sibling species of the Anisakis simplex species complex, with a species designation as Anisakis berlandi n.sp. for A. simplex sp. C. (Nematoda: Anisakidae): Journal of Parasitology, v. 100, p. 199-214.

McClelland, G., 1980a, Phocanema decipiens: growth, reproduction, and survival in seals: Experimental Parasitology, v. 49 , p. $175-187$.

McClelland, G., 1980b, Phocanema decipiens: pathology in seals: Experimental Parasitology, v. 49, p. 405-419.

McClelland, G., 1982, Phocanema decipiens (Nematoda: Anisakinae): experimental infections in marine copepods: Canadian Journal of Zoology, v. 60, p. 502-509.

McClelland, G., 1990, Larval sealworm (Pseudoterranova decipiens) infections in benthic macrofauna, in Bowen, W.D., ed., Population biology of sealworm (Pseudoterranova decipiens) in relation to its intermediate and seal hosts: Canadian Bulletin of Fisheries and Aquatic Sciences, v. 222 , p. $47-65$.

McClelland, G., 1995, Experimental infection of fish with larval sealworm, Pseudoterranova decipiens (Nematoda, Anisakinae), transmitted by amphipods: Canadian Journal of Fisheries and Aquatic Sciences, v. 52 (Supplement 1), p. $140-155$.

McClelland, G., 2002, The trouble with sealworms (Pseudoterranova decipiens) species complex, Nematoda): a review: Parasitology, v. 124, p. S183-S203.
McClelland, G., and Martel, D.J., 2001, Spatial and temporal distributions of larval sealworm, Pseudoterranova decipiens (Nematoda: Anisakinae) in Hippoglossoides platessoides (Pleuronectidae) in the Canadian Maritime Region from 1993 to 1999, in Desportes, G., and McClelland, G., eds., Sealworms in the North Atlantic: ecology and population dynamics: Tromso, Norway, NAMMCO Scientific Publications, v. 3, p. 77-94.

McKerrow, J.H., Sakanari, J., and Deardoff, T.L., 1988, Anisakiasis: revenge of the sushi parasite: The New England Journal of Medicine, v. 319, p. 1228-1229.

Measures, L.N., 1996, Effect of temperature and salinity on development and survival of eggs and free-living larvae of sealworm (Pseudoterranova decipiens): Canadian Journal of Fisheries and Aquatic Sciences, v. 53, p. 2804-2807.

Measures, L.N., Béland, P., Martineau, D., and De Guise, S., 1995, Helminths of an endangered population of beluga, Delphinapterus leucas, in the St. Lawrence Estuary, Canada: Canadian Journal of Zoology, v. 73, p. 1402-1409.

Mercado, R., Torres, P., Muñoz, V., and Apt, W., 2001, Human infection by Pseudoterranova decipiens (Nematoda, Anisakidae) in Chile: report of seven cases: Memorias do Instituto Oswaldo Cruz, Rio de Janeiro, v. 96, p. 653-655.

Murphy, T.M., Berzano, M., O'Keeffe, S.M., Cotter, D.M., McEvoy, S.E., Thomas, K.A., Maoiléidigh, N.P.Ó., and Whelan, K.F., 2010, Anisakid larvae in Atlantic salmon (Salmo salar L.) grilse and post-smolts: molecular identification and histopathology: Journal of Parasitology, v. 96, p. $77-82$.

Myers, B.J., 1976, Research then and now on the Anisakidae nematodes: Transactions of the American Microscopical Society: v. 95 , p. 137-142.

Nadler, S.A., D`Amelio, S., Dailey, M.D., Paggi, L., Siu, S., and Sakanari, J.A., 2005, Molecular phylogenetics and diagnosis of Anisakis, Pseudoterranova, and Contracaecum from Northern Pacific marine mammals: Journal of Parasitology, v. 91, p. 1413-1429.

Nagasawa, K., 1993, Review of human pathogenic parasites in the Japanese common squid (Todarodes pacificus), in Okutani, T., O’Dor, R.K., and Kubodera, T., eds., Recent advances in fisheries biology: Tokyo, Tokai University Press, p. 293-312.

Nagasawa, K., and Moravec, F., 1995, Larval anisakid nematodes of Japanese common squid (Todarodes pacificus) from the Sea of Japan: Journal of Parasitology, v. 81, p. 69-75.

Oshima, T., 1972, Anisakis and anisakiasis in Japan and adjacent area, in Morishita, K., Komiya, Y., and Matsubayashi, H., eds., Progress of medical parasitology in Japan: Tokyo, Meguro Parasitological Museum, v. 4, p. 301-393. 
Oshima, T., 1987, Anisakiasis - is the sushi bar guilty?: Parasitology Today, v. 3, p. 44-48.

Oshima, T., Kobyashi, A., Kumada, M., Koyama, T., Kagei, N., and Nemoto, T., 1968, Experimental infection with second-stage larvae of Anisakis sp. on Euphausia similis and Euphausia pacifica: Japanese Journal of Parasitology, v. 17, p. 585-586 (in Canadian Translation of Fisheries and Aquatic Sciences, 1994, no. 5629, original in Japanese).

Paggi, L., Mattiucci, S., Gibson, D.I., Berland, B., Nascetti, G., Cianchi, R., and Bullini, L., 2000, Pseudoterranova decipiens species A and B (Nematoda, Ascaridoidea): nomenclatural designation, morphological diagnostic characters and genetic markers: Systematic Parasitology, v. 45, p. 185-197.

Paggi, L., Nascetti, G., Cianchi, R., Orecchia, P., Mattiucci, S., D’Amelio, S., Berland, B., Brattey, J., Smith, J.W., and Bullini, L., 1991, Genetic evidence for three species within Pseudoterranova decipiens (Nematoda, Ascaridida, Ascaridoidea) in the North Atlantic and Norwegian and Barents Seas: International Journal for Parasitology, v. 21, p. 195-212.

Palm, H.W., 1999, Ecology of Pseudoterranova decipiens (Krabbe, 1878) (Nematoda: Anisakidae) from Antarctic waters: Parasitology Research, v. 85, p. 638-646.

Power, H.E., 1958, The effect of various lighting conditions on the efficiency of 'candling' cod fillets for detection of parasites: Journal of the Fisheries Research Board of Canada, v. 15 , p. 537-542.

Power, H.E., 1961, Slicing of fillets as an aid in detection and removal of codworms from Atlantic cod fillets: Journal of the Fisheries Research Board of Canada, v. 18, p. 137-140.

Ramakrishna, N.R., and Burt, M.D.B., 1991, Tissue response of fish to invasion by larval Pseudoterranova decipiens (Nematoda: Ascaridoidea): Canadian Journal of Fisheries and Aquatic Sciences, v. 48, p. 1623-1628.

Rausch, R., 1953, Studies on the helminth fauna of Alaska. XIII. Disease in the sea otter, with special reference to helminth parasites: Ecology, v. 34, p. 584-604.

Reddy, A., and Fried, B., 2008, Atopic disorders and parasitic infections: Advances in Parasitology, v. 66, p. 149-191.

Ridgway, S.H., Geraci, J.R., and Medway, W., 1975, Diseases of pinnipeds: Rapport et Procès-Verbaux des Réunions, Conseil Permanent International pour l'Exploration de la Mer, v. 169, p. 327-337.
Riley, J., 1972, The pathology of Anisakis nematode infections of the fulmar Fulmarus glacialis: Ibis, v. 114, p. 102-104.

Rodenburg, W., and Wielinga, W.J., 1960, Eosinfiele flegmone van de dunne darme, veroorzakt door een worm: Nederlandsch Tidjscrift voor Geneeskunde, v. 104, p. 417-421.

Simard, M., 1997, Population dynamics of Anisakis simplex in harbor porpoise (Phocoena phocoena): Montreal, McGill University, Master of Science Thesis.

Smith, J.W., 1971, Thysanoessa inermis and T. longicaudata (Euphausiidae) as first intermediate hosts of Anisakis sp. (Nematoda: Ascaridata) in the Northern North Sea, to the North of Scotland and at Faroe: Nature, v. 234, p. 478.

Smith, J. W., 1974, Experimental transfer of Anisakis sp. larvae (Nematoda: Ascaridida) from one fish host to another: Journal of Helminthology, v. 48, p. 229-234.

Smith, J.W., 1989, Ulcers associated with larval Anisakis simplex B (Nematoda: Ascaridoidea) in the forestomach of harbor porpoises Phocena phocoena (L.): Canadian Journal of Zoology, v. 67, p. 2270-2276.

Smith, J.W., 1999, Ascaridoid nematodes and pathology of the alimentary tract and its associated organs in vertebrates, including man: a literature review: Helminthological Abstracts, v. 68, p. 49-96.

Smith, J.W., and Hemmingsen, W., 2003, Atlantic cod Gadus morhua L.: visceral organ topography and the asymmetrical distribution of larval ascaridoid nematodes in the musculature: Ophelia, v. 57, p. 137-144.

Smith, J.W., and Wootten, R., 1975, Experimental studies on the migration of Anisakis sp. larvae (Nematoda: Ascaridida) into the flesh of herring, Clupea harengus L.: International Journal for Parasitology, v. 5, p. 133-136.

Smith, J.W., and Wootten, R., 1978, Anisakis and anisakiasis: Advances in Parasitology, v. 16, p. 93-163.

Sprengel, G., and Lüchtenberg, H., 1991, Infection by endoparasites reduces maximum swimming speed of European smelt Osmerus eperlanus and Europen eel Anguilla anguilla: Diseases of Aquatic Organisms, v. 11, p. 31-35.

Stroud, R.K., and Dailey, M.D., 1978, Parasites and associated pathology observed in pinnipeds stranded along the Oregon coast: Journal of Wildlife Diseases, v. 14, p. 292-298.

Stroud, R.K., and Roff, T.J., 1979, Causes of death in marine mammals stranded along the Oregon coast: Journal of Wildlife Diseases, v. 15, p. 91-97. 
Sugimachi, K., Inokuchi, K., Ooiwa, T., Fujino, T., and Ishii, Y., 1985, Acute gastric anisakiasis: analysis of 178 cases: Journal of the American Medical Association, v. 253, p. 1012-1013.

Torres, P., Jercic, M.I., Weitz, J.C., Dobrew, E.K., and Mercado, R.A., 2007, Human pseudoterranovosis, an emerging infection in Chile: Journal of Parasitology, v. 93, p. $440-443$.

Ugland, K.I., Stromnes, E., Berland, B., and Aspholm, P.E., 2004, Growth, fecundity and sex ratio of adult whaleworm (Anisakis simplex; Nematoda, Ascaridoidea, Anisakidae) in three whale species from the North-East Atlantic: Parasitology Research, v. 92, p. 484-489.

U.S. Food and Drug Administration, 2009, Food code. U.S. Department of Health and Human Services, Public Health Service: http://www.fda.gov/Food/GuidanceRegulation/ RetailFoodProtection/FoodCode/UCM2019396.htm.

Uspenskaya, A.V., 1963, Parasitic fauna of benthic crustaceans of the Barents Sea: Murmansk Institute of Marine Biology, Publishing House of the USSR Academy of Sciences, Moscow-Leningrad (in Canadian Translation of the Fisheries and Aquatic Sciences, 1995, no. 5648, p. 61-71, original in Russion.)

Valdimarsson, G., Einarsson, H., and King, F.J., 1985, Detection of parasites in fish muscle by candling technique: Journal of Association of Official Analytical Chemistry, v. 68, p. $549-551$.

Valiñas, B., Lorenzo, S., Eiras, A., Figueiras, A., Sanmartin, M. L., and Ubeira, F.M., 2001, Prevalence of and risk factors for IgE sensitization to Anisakis simplex in a Spanish population: Allergy, v. 56, p. 667-671.

van Thiel, P.H., Kuipers, F.C., and Roskam, T.H., 1960: A nematode parasitic to herring, causing acute abdominal syndromes in man: Tropical and Geographical Medicine, v. 12 , p. $97-113$.

Wharton, D.A., and Aalders, O., 2002, The response of Anisakis larvae to freezing: Journal of Helminthology, v. 76, p. 363-368.

Zhu, X.Q., D’Amelio, S., Palm, H.W., Paggi, L., GeorgeNascimento, M., and Gasser, R.B., 2002, SSCP-based identification of members within the Pseudoterranova decipiens complex (Nematoda: Ascaridoidea: Anisakidae) using genetic markers in the internal transcribed spacers of ribosomal DNA: Parasitology, v. 124, p. 615-623. 


\section{Glossary}

A

aberrant Departing from the usual course; unusual.

abiotic Nonliving.

abscess A localized collection of pus (thick, yellowish fluid made of white blood cells, dead tissue cells, and cellular debris) surrounded by inflamed tissue.

amphipod A small, shrimplike crustacean within the taxonomic order Amphipoda, having a laterally compressed body and living mainly in aquatic habitats. See crustacean, scud.

anadromous Migrating up rivers from the ocean to breed in fresh water.

anisakid A roundworm within the family Anisakidae, including members of the genera Anisakis and Pseudoterranova. See genera, taxonomic.

antibody A protein formed in the body of a vertebrate that is used by the immune system to identify and neutralize the effects of foreign invading proteins (antigens), such as those in bacteria and viruses.

ascarid Any parasitic nematode worm of the family Ascaridae. See parasite, nematode.

\section{B}

benthic Pertaining to the bottom of the ocean or lake or the organisms that live there.

C

cephalopod A mollusk within the taxonomic class Cephalopoda having a large head and tentacles, for example, octopus, squid, cuttlefish, and nautilus. See taxonomic.

cetacean A marine mammal within the taxonomic order Cetacea having no hind limbs, flippers as forelimbs, and a blowhole for breathing, for example, whales, dolphins, and porpoises. See taxonomic.

copepod A tiny, aquatic crustacean within the taxonomic subclass Copepoda, having an elongated body and a forked tail. See crustacean, taxonomic. crustacean An invertebrate animal within the taxonomic class Crustacea, having a segmented body, chitinous exoskeleton, and jointed limbs, for example, lobsters, crabs, shrimp, barnacles, and pill bugs. See invertebrate, taxonomic.

computed tomography (CT) scan An imaging method used to construct a crosssectional image of body structures in a body plane produced by $\mathrm{x}$-ray absorption of the structures in the image plane.

dead-end host A host in which a parasite cannot complete its development and transmission in order to continue its life cycle. See host, definitive host, intermediate host, parasite.

decapod A crustacean within the taxonomic order Decapoda, having 10 legs, for example, crab, lobster, and shrimp. See crustacean, taxonomic.

definitive host An organism in which sexually mature stages of a parasite occur. Also called the final host. See host, parasite.

dermatitis Inflammation of the skin.

\section{E}

encapsulated Enclosed within a protective layer of cells.

endoscopy Visual examination of the inside of organs and cavities of the body using an illuminated, flexible optical tube.

entomologist A scientist who studies insects.

enzyme A protein produced by a living cell that functions to increase or decrease the rate of metabolic processes.

eosinophils The white blood cells involved in combating parasitic infections and controlling allergic reactions. See parasitic.

estuarine Pertaining to an estuary, an area where a river nears the ocean and fresh water mixes with tidal salt water.

euphausiid A small shrimplike crustacean within the taxonomic order Euphausiacea. See crustacean, taxonomic, krill.

eviscerate To remove the internal organs; disembowel. 


\section{F}

fish Refers to finfish, which are coldblooded strictly aquatic vertebrates with a well differentiated skull and a bony skeleton, rather than shellfish (see invertebrates) and jawless fishes.

\section{G}

gastric Pertaining to the stomach.

gastroendoscopy Endoscopy of the stomach. See endoscopy.

gastrointestinal tract The tubular organs that form a digestive pathway from the mouth to the anus, including the esophagus, stomach, and intestines.

genera Plural of genus. See genus.

genus A taxonomic group between family and species containing organisms that share common characteristics. See taxonomic, genera.

\section{H}

histologic Pertaining to histology, the study of the microscopic structure of tissues.

host An organism that harbors or nourishes microbes, viruses, and parasites. See parasite.

\section{I}

Immunoglobulin E (IgE) A type of antibody that is important in allergic reactions. See antibody.

immune status Refers to the host's ability to fight infections. See host.

intensity Number of parasites in an infected host. See parasite, host.

intermediate host An organism in or on which the larval stage of a parasite develops but does not sexually reproduce. See host, parasite, larva/larval.

Inuit Native people of northern North America, inhabiting areas from Greenland and eastern Canada to Alaska.

invertebrates Animals lacking a spinal column, for example, insects and crustaceans; vertebrates, in contrast, possess a spinal column. See crustacean.

isopod A crustacean within the taxonomic order Isopoda, characterized by a flattened body and gills located on abdominal append- ages; most are aquatic bottom-dwellers in fresh or salt water. See crustacean, taxonomic.

krill A small shrimplike crustacean within the taxonomic order Euphausiacea. See crustacean, taxonomic, euphausiid.

\section{L}

larva/larval The immature, early form of an organism that at birth or hatching is not like its parent and has to undergo a series of form and size changes before assuming adult features.

lesion An abnormal change in tissue or an organ due to disease or injury.

light microscopy A technique using visible light and single or multiple lenses (microscope) to obtain a magnified view of a sample.

luminal Pertaining to the lumen, the inner open space of a tubular organ.

\section{M}

morphology The study of the form and structure of an organism or its parts.

mucosa A mucous membrane or moist tissue layer lining hollow organs such as the stomach and cavities of the body.

mysid A small, shrimplike crustacean within the taxonomic orders Mysida or Lophogastrida found in salt and fresh water. See crustacean, taxonomic.

\section{N}

nematode An unsegmented, cylindrical parasitic worm within the taxonomic class Nematoda; roundworm. See parasitic, taxonomic.

\section{0}

$\mathbf{P}$

parasite An organism that lives in or on another organism of a different species from which it derives nutrients and shelter.

parasitic Pertaining to parasites. See parasite. 
parasitologist A scientist who studies parasites. See parasite.

pelagic Pertaining to the upper waters of the open ocean or the organisms that live there.

pepsin An enzyme produced in the stomach that breaks down proteins.

perforation An abnormal hole in an organ or the act of creating such a hole.

peritonitis Inflammation of the peritoneum, the membrane lining the abdominal cavity and internal organs.

physiological status Refers to the host's physiology, the normal functioning of an organism.

pinniped A marine mammal within the taxonomic suborder Pinnipedia having finlike flippers as feet, such as walrus, sea lions, fur seals, and earless seals. See taxonomic.

polychaete A segmented worm, generally marine, within the taxonomic class Poly-

chaeta. See taxonomic.

prevalence The total number of cases of a disease divided by the number of hosts examined in a population at a given time. See host.

$\mathbf{0}$

$\mathbf{R}$

radiology The science of using electromagnetic radiation or sound waves to make images of structures within the body, including x-rays, computed tomography (CT) scans, magnetic resonance imaging (MRI), and ultrasound. See computed tomography scan.

roundworm See nematode.

\section{S}

scud A tiny crustacean resembling a shrimp. See crustacean, amphipod.

sensu lato In a broad or wide sense.

sensu stricto In a strict or narrow sense.

spawn To deposit eggs or produce offspring.

species A population or populations of closely related and similar organisims that freely interbreed with one another in natural conditions but not with members of other species. susceptibility/susceptible Pertaining to the ability of an animal to become infected by a disease-causing organism or to develop disease after becoming infected.

\section{T}

taxonomic Pertaining to taxonomy. See taxonomy.

taxonomy The systematic principles and procedures of grouping and arranging organisms into a hierarchical order (below).

\begin{tabular}{c}
\hline $\begin{array}{c}\text { Taxonomic hierarchy, } \\
\text { from general to specific }\end{array}$ \\
\hline Kingdom \\
Phylum \\
Class \\
Order \\
Family \\
Subfamily \\
Genus \\
Species \\
\hline
\end{tabular}

transport host An organism in which a parasite survives without further development. See parasite, host.

\section{U}

V

vent The common opening of the intestinal, genital, and urinary tracts in fish, reptiles, and birds. See fish.

viscera The internal organs, particularly of the thoracic and abdominal cavities, such as the heart, lungs, liver, kidneys, and intestines.

visceral Pertaining to viscera. See viscera.

\section{W}

$\mathbf{X}$

$\mathbf{Y}$

Z

zoonotic Transmissible between animals and humans, and vice versa. 


\section{Appendixes}

Appendix 1. Common and Scientific Names for Species Cited

Appendix 2. Important Literature About Anisakis spp. and Pseudoterranova spp. 


\section{Appendix 1. Common and Scientific Names for Species Cited}

\begin{tabular}{ll}
\hline \multicolumn{1}{c}{ Common name } & \multicolumn{1}{c}{ Scientific name } \\
\hline Black-tailed gull & Birds crassirostris \\
Herring gull & Larus argentatus \\
Northern fulmar & Fulmarus glacialis \\
Swinhoe's storm petrel & Oceanodroma monorhis \\
Tufted puffin & Fratercula cirrhata=Lunda cirrhata \\
Japanese cormorant & Phalacrocorax capillatus \\
\hline
\end{tabular}

\begin{tabular}{ll}
\multicolumn{2}{c}{ Crustaceans } \\
\hline Crabs & Order Decapoda \\
Crayfish & Order Decapoda \\
Krill & Order Euphausiacea \\
Amphipods & Order Amphipoda \\
Lobsters & Order Decapoda \\
Shrimp & Order Decapoda \\
\hline
\end{tabular}

Fish

\begin{tabular}{ll}
\hline American plaice & Hippoglossoides platessoides \\
Anchovy & Family Engraulidae \\
Atlantic cod & Gadus morhua \\
Atlantic salmon & Salmo salar \\
Brook trout & Salvelinus fontinalis \\
Capelin & Mallotus villosus \\
Eelpout & Family Zoarcidae \\
Flatfish & Order Pleuronectiformes \\
Herring & Family Clupeidae \\
Mackerel & Scomber scombrus \\
Monkfish & Family Lophiidae \\
Rainbow smelt & Osmerus mordax \\
Redfish & Sebastes scombrus \\
Salmon & Family Salmonidae \\
Sculpin & Family Cottoidei \\
Silver hake & Merluccius bilinearis \\
Smelt & Family Osmeridae \\
\end{tabular}




\begin{tabular}{|c|c|}
\hline Common name & Scientific name \\
\hline \multicolumn{2}{|c|}{ Mammals } \\
\hline Andrew's beaked whale & Mesoplodon bowdoini \\
\hline Bearded seal & Erignathus barbatus \\
\hline Beluga & Delphinapterus leucas \\
\hline Blainville's beaked whale & Mesoplodon densirostris \\
\hline Bottlenose dolphin & Tursiops truncata \\
\hline Brown bear & Ursus arctos \\
\hline California sea lion & Zalophus californianus \\
\hline Caspian seal & Phoca caspica \\
\hline Common dolphin & Delphinus delphis \\
\hline Costero & Sotalia guianensis \\
\hline Cuvier's beaked whale & Ziphius cavirostris \\
\hline Dog (domestic) & Canis lupus familiaris \\
\hline Dwarf sperm whale & Kogia sima \\
\hline False killer whale & Pseudorca crassidens \\
\hline Gervais' beaked whale & Mesoplodon europaeus \\
\hline Gray's beaked whale & Mesoplodon grayi \\
\hline Gray seal & Halichoerus grypus \\
\hline Harbor porpoise & Phocoena phocoena \\
\hline Harbor seal & Phoca vitulina \\
\hline Harp seal & Pagophilus groenlandicus \\
\hline Hooded seal & Cystophora cristata \\
\hline Killer whale & Orcinus orca \\
\hline Long-finned pilot whale & Globicephala melas \\
\hline Mediterranean monk seal & Monachus monachus \\
\hline Minke whale & Balaenoptera acutorostrata \\
\hline Northern elephant seal & Mirounga angustirostris \\
\hline Northern right whale dolphin & Lissodelphis borealis \\
\hline Northern (Steller) sea lion & Eumetopias jubatus \\
\hline Pantropical spotted dolphin & Stenella attenuata \\
\hline
\end{tabular}




\begin{tabular}{|c|c|}
\hline Common name & Scientific name \\
\hline \multicolumn{2}{|c|}{ Mammals-Continued } \\
\hline Pygmy right whale & Caperea marginata \\
\hline Pygmy sperm whale & Kogia breviceps \\
\hline Ringed seal & Pusa hispida \\
\hline Rough-toothed dolphin & Stenella longirostris \\
\hline Sea otter & Enhydra lutris \\
\hline Short-finned pilot whale & Globicephala macrorhynchus \\
\hline South American sea lion & Otaria flavescens \\
\hline Sperm whale & Physeter macrocephalus \\
\hline Spinner dolphin & Stenella longirostris \\
\hline Southern elephant seal & Mirounga leonina \\
\hline Strap-toothed beaked whale & Mesoplodon layardii \\
\hline Striped dolphin & Stenella coeruleoalba \\
\hline True's beaked whale & Mesoplodon mirus \\
\hline Tucuxi & Sotalia fluviatilis \\
\hline Weddell seal & Leptonychotes weddellii \\
\hline White beaked dolphin & Lagenorhynchus albirostris \\
\hline \multicolumn{2}{|c|}{ Mollusks } \\
\hline Squid & Class Cephalapoda, Order Teuthida \\
\hline Cuttlefish & Class Cephalapoda, Order Sepiida \\
\hline
\end{tabular}




\section{Appendix 2. Important Literature About Anisakis spp. and Pseudoterranova spp.}

\section{Anisakiosis and Pseudoterranovosis}

Berland, B., and Fagerholm, H.-P., 1994, Thirty years of anisakid research, and future trends: Bulletin of the Scandinavian Society of Parasitology, v. 4, p. 40-46.

Cheng, T.C., 1976, The natural history of anisakiasis in animals: Journal of Milk and Food Technology, v. 39, p. 32-46.

Ishikura, H., Kikuchi, K., Nagasawa, K., Ooiwa, T., Takamiya, H., Sato, N., and Sugane, K., 1992, Anisakidae and anisakidosis, in Sun, T., ed., Progress in clinical parasitology, v. 3: New York, Springer-Verlag, p. 43-102.

Jackson, G.J., 1975, The "new disease" status of human anisakiasis and North American cases: a review: Journal of Milk and Food Technology, v. 38, p. 769-773.

Margolis, L., 1977, Public health aspects of "codworm" infection: a review: Journal of the Fisheries Research Board of Canada, v. 34, p. 887-898.

Myers, B.J., 1975, The nematodes that cause anisakiasis: Journal of Milk and Food Technology, v. 38, p. 774-782.

Oshima, T., 1972, Anisakis and anisakiasis in Japan and adjacent area in Morishita, K., Komiya, Y., and Matsubayashi, H. eds., Progress of medical parasitology in Japan, v. 4: Tokyo, Meguro Parasitological Museum, p. 301-393.

Oshima, T., 1987, Anisakiasis-is the sushi bar guilty?: Parasitology Today, v. 3, p. 44-48.

Sakanari, J.A., 1990, Anisakis - from the platter to the microfuge: Parasitology Today, v. 6, p. 323-327.

Smith, J.W., 1999, Ascaridoid nematodes and pathology of the alimentary tract and its associated organs in vertebrates, including man: a literature review: Helminthological Abstracts, v. 68, p. 49-96.

Smith, J.W., and Wootten, R., 1978, Anisakis and anisakiasis: Advances in Parasitology, v. 16, p. 93-163.

Biology and transmission of whaleworm, Anisakis simplex

Anderson, R.C., 2000, The superfamily Ascaridoidea, in Anderson, R.C., ed., Nematode parasites of vertebrates: their development and transmission: Oxon, United Kingdom, CABI Publishing, p. 267-314.

Nagasawa, K., 1990, The life cycle of Anisakis simplex: a review, in Ishikura, H. and K. Kikuchi, eds., Intestinal anisakiasis in Japan: Tokyo, Japan, SpringerVerlag, p. 31-40.
Nagasawa , K., and Moravec, F., 1995, Larval anisakid nematodes of Japanese common squid (Todarodes pacificus) from the Sea of Japan: Journal of Parasitology, v. 81, p. 69-75.

Shimazu, T., 1974, Ecology, in Nippon, Suisan Gakkaishi, ed., Gyorui to anisakisu: Tokyo, Koseisha-Koseikaku, Fisheries and Marine Service Translation Series no. 3417 (1975). p. 23 - 43 (in Japanese).

Smith, J.W., and Wootten, R., 1978, Anisakis and anisakiasis: Advances in Parasitology, v. 16, p. 93-163.

\section{Biology and transmission of sealworm Pseudoterranova decipiens, particularly from a fishery viewpoint}

Anderson, R.C., 2000, The superfamily Ascaridoidea, in Anderson, R.C., ed., Nematode parasites of vertebrates: their development and transmision: Oxon, United Kingdom, CABI Publishing, p. 267-314.

Bowen, W.D. ed., 1990, Population biology of sealworm (Pseudoterranova decipiens) in relation to its intermediate and seal hosts: Canadian Bulletin of Fisheries and Aquatic Sciences, v. 222, 306 p.

Burt, M.D.B. 1994, The sealworm situation, in Scott, M.E., and Smith, G., eds., Parasitic and infectious diseases: San Diego, Calif., Academic Press, p. 347-362.

Desportes, G., and McClelland, G., eds., 2001, Sealworms in the North Atlantic: ecology and population dynamics: Tromso, Norway, NAMMCO Scientific Publications, v. 3, $171 \mathrm{p}$.

Hafsteinsson, H., and Rizvi, S.H., 1987, A review of the sealworm problem: biology, implications and solutions: Journal of Food Production, v. 50, p. 70-84.

Myers, B.J., 1960, On the morphology and life history of Phocanema decipiens (Krabbe, 1878) Myers, 1959 (Nematoda: Anisakidae): Canadian Journal of Zoology, v. 38, p. 331-344. 
Publishing support was provided by the USGS Columbus Publishing Service Center. Editing by Elizabeth Enright.

Layout, illustrations and cover by Rosemary Stenback. 
For more information concerning this report, contact:

Director

U.S. Geological Survey

National Wildlife Health Center

6006 Schroeder Road

Madison, WI 53711-6223

jsleeman@usgs.gov

or visit our Web site at:

http://www.nwhc.usgs.gov/ 


\section{窟}

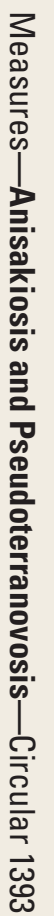

